\title{
The Emperor Has No Clothes: Confronting the D.C. Circuit's Usurpation of SEC Rulemaking Authority
}

\section{James D. Cox $^{*} \&$ Benjamin J.C. Baucom ${ }^{* *}$}

The Dodd-Frank Wall Street Reform and Consumer Protection $\mathrm{Act}^{1}$ of 2010 introduced the most sweeping reforms of financial markets since the Great Depression. Nestled among its numerous provisions was the amendment to Section 14(a) of the Securities Exchange Act of 1934 expressly authorizing the Securities and Exchange Commission (SEC) to adopt rules for shareholders to nominate directors to the boards of reporting companies. ${ }^{2}$ Financial institutions had long lobbied the SEC for a rule providing shareholders access to the nominating process of publicly held corporations. $^{3}$ Their cause gained momentum with a 2003 SEC staff report recommending that large, long-term holders, under very limited circumstances, should have the right to nominate a minority of the directors to be elected. ${ }^{4}$ After that report, a battle royal ensued, a pro-access chairman was terminated, and under the new SEC chairman, the SEC sidetracked shareholder access and even curbed the institutions' access to the proxy machinery as a means to authorize shareholder nominations to the board. ${ }^{5}$

* Brainerd Currie Professor of Law, Duke University School of Law.

** Law clerk to Justice Don R. Willett of the Supreme Court of Texas; J.D., Duke University School of Law, May 2011. This paper reflects solely the authors' views, not those of the Supreme Court of Texas or any of its justices. The authors are grateful for the comments received from the participants at the Texas Law Review Symposium, RESHAPING CAPITAL MARKETS \& INSTITUTIONS: TWENTY YEARS ON, and are especially indebted to the commentator on this paper, Professor Ronald Gilson. We have also benefitted from the research assistances of Messrs. Stephen Atherstone, Jevon Conroy, and David Riesenberg.

1. Pub. L. No. 111-203, 124 Stat. 1376 (2010).

2. Id. § 971. The amendment provided:

(2) The rules and regulations prescribed by the Commission under paragraph (1) may include-

(A) a requirement that a solicitation of proxy, consent, or authorization by (or on behalf of) an issuer include a nominee submitted by a shareholder to serve on the board of directors of the issuer; and

(B) a requirement that an issuer follow a certain procedure in relation to

Id. a solicitation described in subparagraph (A).

3. See, e.g., S.E.C. Sued Over Board Nomination Rule for Investors, N.Y. TIMES DEALBOOK (Sept. 30, 2010, 4:26 AM), http://dealbook.nytimes.com/2010/09/30/s-e-c-sued-over-boardnomination-rule-for-investors (highlighting the lobbying efforts of public pension funds).

4. Security Holder Director Nominations, Exchange Act Release No. 48,626, Investment Company Act Release No. 26,206, 68 Fed. Reg. 60,784, 60,787 (proposed Oct. 23, 2003).

5. The SEC interpreted its shareholder proposal provision, Rule 14a-8, 17 C.F.R. § 240.14a8(i)(8) (2005), to permit companies to omit a bylaw proposal setting forth a procedure by which stockholders could nominate directors because the proposal related to the election of directors. Am. Fed'n of State, Cnty. \& Mun. Emps. v. AIG, 462 F.3d 121, 126 (2d Cir. 2006). The Second Circuit 
Then, with the imprimatur of Dodd-Frank, ${ }^{6}$ the SEC acted, albeit timidly, to provide, in Rule 14a-11, a process for limited shareholder board nominations. In broad overview, Rule 14a-11 permitted a shareholder or group of shareholders that held at least three percent of the voting power for over three years to nominate a maximum of twenty-five percent of the board. $^{7}$ Institutions rejoiced, but only briefly; Rule 14a-11 never became operative. The rule was immediately challenged, and the SEC suspended its effect until the legal dispute was resolved. ${ }^{8}$

In Business Roundtable v. SEC, ${ }^{9}$ the D.C. Circuit ultimately invalidated Rule 14a-11, holding that the SEC acted arbitrarily and capriciously in adopting it. ${ }^{10}$ In so ruling, the D.C. Circuit followed a now familiar path of invalidating SEC rulemaking efforts on the ground that the SEC failed to meet the review standard ${ }^{11}$ (hereinafter Review Standard), which mandates that "the Commission shall ... consider, in addition to the protection of investors, whether the action will promote efficiency, competition, and capital formation."12 Previously this provision was invoked by the D.C. Circuit to invalidate SEC rules calling for seventy-five percent of a registered

Court of Appeals rejected the SEC's position. Id. at 129-30. Thereupon the SEC amended the rule to expressly authorize excluding a proposal if it "relates to a nomination" of a director. Shareholder Proposals Relating to the Election of Directors, Exchange Act Release No. 56,914, Investment Company Act Release No. 28,075, 72 Fed. Reg. 70,450, 70,456 (Dec. 11, 2007) (codified at 17 C.F.R. pt. 240). Earlier the SEC had proposed two conflicting approaches regarding shareholder nominations. Shareholder Proposals, Exchange Act Release No. 56,160, Investment Company Act Release No. 27,913, 72 Fed. Reg. 43,466, 43,466 (proposed Aug. 3, 2007) (creating a device to allow inclusion of shareholder proposals in a company's proxy statement); id. at 43,487 (proposing an amendment to proxy rules that would exclude shareholder proposals from the company's proxy statement “[i]f the proposal relates to a nomination or an election for membership on the company's board of directors or analogous governing body or a procedure for such nomination or election"). States have not been idle in this debate. See, e.g., DEL. CoDE ANN. tit. 8, §§ 112, 113 (2011) (authorizing bylaws providing for the nomination of directors by shareholders and reimbursement of such nominees' election expenses); MODEL BUS. CORP. ACT § 2.06(c) (2010) (providing for authorization of the same). Cf. CA, Inc. v. AFSCME Emps. Pension Plan, 953 A.2d 227 (Del. 2008) (holding a stockholder-proposed bylaw calling for reimbursement of an insurgent's reasonable proxy expenses was a proper subject for shareholder action because it related to the process of carrying out the limited shareholder franchise).

6. See infra notes 161-62 and accompanying text.

7. Facilitating Shareholder Director Nominations, Securities Act Release No. 9136, Exchange Act Release No. 62,764, Investment Company Act Release No. 29,384, 75 Fed. Reg. 56,668, 56,674-75 (Sept. 16, 2010).

8. See Facilitating Shareholder Director Nominations, Securities Act Release No. 9151, Exchange Act Release No. 63,109, Investment Company Act Release No. 29,462, 75 Fed. Reg. 64,641, 64,641 (Oct. 20, 2010) (announcing that effective and compliance dates for amendments to, inter alia, 17 C.F.R. pt. 240 would be indefinitely delayed until further notice).

9. 647 F.3d 1144 (D.C. Cir. 2011).

10. Id. at 1156 .

11. Id. at 1148 .

12. Securities Exchange Act of 1934 § 3(f), 15 U.S.C. § 78c(f) (2006). The three other major securities laws administered by the SEC contain the same Review Standard. See Securities Act of 1933 § 2(b), 15 U.S.C. § 77b(b) (2006); Investment Company Act of 1940 § 2(c), 15 U.S.C. § 80a2(c) (2006); Investment Advisers Act of 1940 § 202(c), 15 U.S.C. § 80b-2(c) (2006). 
mutual fund board, including the board chairman, to be independent of the fund's investment advisor, ${ }^{13}$ and classifying so-called fixed indexed annuities so that they would no longer enjoy an exemption from the Securities Act. ${ }^{14}$

In holding that the SEC failed to fulfill the statutory Review Standard when considering the impact of Rule 14a-11 on efficiency, competition, and capital formation, Business Roundtable summarized the SEC's faults as follows:

Here the Commission inconsistently and opportunistically framed the costs and benefits of the rule; failed adequately to quantify the certain costs or to explain why those costs could not be quantified; neglected to support its predictive judgments; contradicted itself; and failed to respond to substantial problems raised by commenters. ${ }^{15}$

It is not our purpose here to disagree with any of these evidentiary conclusions. What we report here is that the level of review invoked by the D.C. Circuit in Business Roundtable and its earlier decisions is dramatically inconsistent with the standard enacted by Congress. Our conclusion is that the D.C. Circuit has assumed for itself a role opposed to the one Congress prescribed for courts reviewing SEC rules.

\section{The Review Standard According to the D.C. Circuit}

Business Roundtable is distinctive in its close review of the SEC's failings in the agency's consideration and adoption of Rule 14a-11. We summarize in this paragraph the most notable points raised in Judge Ginsburg's opinion. We do this to provide a fully textured understanding of what the D.C. Circuit believes is required by the mandate that the SEC consider a rule's impact on efficiency, competition, and capital formation. Rising from a close review of the decision is the D.C. Circuit's view that SEC rulemaking must attempt, if not complete, an accurate cost-benefit determination. Thus, Judge Ginsburg faults the SEC's cost-benefit assessments because they "had no basis beyond mere speculation"16 or because the SEC failed "to estimate and quantify the costs it expected companies to incur." ${ }^{17}$ Based on these identified failings, the D.C. Circuit observed that "the Commission has not sufficiently supported its conclusion that increasing the potential for election of directors nominated by shareholders will result in improved board and company performance and

13. Chamber of Commerce v. SEC, 412 F.3d 133, 142-44 (D.C. Cir. 2005). The D.C. Circuit heard a second challenge to the same rule, but that decision did not apply or analyze the statutory Review Standard regarding efficiency, competition, and capital formation. See Chamber of Commerce v. SEC, 443 F.3d 890, 894 (D.C. Cir. 2006) (stating that the focus was on whether the Commission relied on material not in the rulemaking record in deciding not to modify the rule).

14. Am. Equity Inv. Life Ins. Co. v. SEC, 613 F.3d 166, 167-68 (D.C. Cir. 2010).

15. Bus. Roundtable, 647 F.3d at 1148-49.

16. Id. at 1150 .

17. Id. 
shareholder value."18 In areas where the SEC discounted the costs associated with its rule, the D.C. Circuit condemned that reasoning as "illogical and, in an economic analysis, unacceptable.”"19 A good illustration of the opinion's requirement that costs and benefits be assessed is its rebuke of the SEC for failing to consider, "[i]n weighing the rule's costs and benefits," the extent to which the new rule would "take the place of traditional proxy contests." ${ }^{20}$ As the court explained, "[w]ithout this crucial datum, the Commission has no way of knowing whether the rule will facilitate enough election contests to be of net benefit.",21

Until very recent years, SEC-adopted rules enjoyed a blissful existence before the D.C. Circuit. ${ }^{22}$ The turning point came in 2005 when, in Chamber of Commerce v. SEC, ${ }^{23}$ the Chamber challenged rules the SEC adopted under the Investment Company Act that exempted otherwise prohibited transactions if at least seventy-five percent of a mutual fund's board of directors, and the board's chair, were independent. ${ }^{24}$ The SEC broadly stated that it did not expect the exemption "to have a significant effect on efficiency, competition and capital formation" in light of the fact that "many funds [had] already adopted the required practices." 25 The SEC did acknowledge that the rule would entail quantifiable costs, but it was confident there would be unquestionable benefits. ${ }^{26}$

Chamber of Commerce, another opinion authored by Judge Ginsburg, held that the SEC violated the Administrative Procedure Act (APA) with regards to considering the costs of the new rules. ${ }^{27}$ For both rules, the SEC

\footnotetext{
18. Id. at 1151 .

19. Id.

20. Id. at 1153 .

21. Id. (emphasis added).
}

22. This view of the quiet life the SEC earlier enjoyed before the D.C. Circuit has been previously explored by one of the authors. See James D. Cox, Premises for Reforming the Regulation of Securities Offerings: An Essay, 63 LAW \& CONTEMP. PROBS. 11, 37-39 (2000) (noting that with the exception of an earlier decision on another matter by the Business Roundtable, "[f]ew decisions have seriously questioned the validity of an SEC rule"). We distinguish the cases discussed in this article from the earlier reversal the SEC suffered in Business Roundtable, which held that the SEC lacked the substantive authority to impose a one-share, one-vote requirement for public companies. Bus. Roundtable v. SEC, 905 F.2d 406, 408 (D.C. Cir. 1990). None of the cases reviewed here held that the SEC lacked the substantive authority to regulate the matter at issue.

23. 412 F.3d 133 (D.C. Cir. 2005).

24. Id. at 136-37. The SEC enacted these rules, by a split vote of three to two, under the Investment Company Act. See Investment Company Governance, Investment Company Act Release No. 26,520, 69 Fed. Reg. 46,378, 46,378, 46,390 (Aug. 2, 2004) (codified at 17 C.F.R. pt. 270) (adopting amendments to the Investment Company Act over the dissent of two commissioners).

25. Investment Company Governance, 69 Fed. Reg. at 46,388.

26. See id. at 46,386-87 (analyzing the costs and benefits of the amendments to the Investment Company Act).

27. See Chamber of Commerce, 412 F.3d at 144 ("In sum, the Commission violated its obligation under 15 U.S.C. § 80a-2(c), and therefore the APA, in failing adequately to consider the costs imposed upon funds by the two challenged conditions.”). 
stated, as part of its announcement of the final rules, that it would be difficult to quantify the potential costs for a fund to comply. ${ }^{28}$ The court stated that this uncertainty did "not excuse the Commission from its statutory obligation to determine as best it can the economic implications of the rule it has proposed." 29 The court reasoned that "uncertainty ... does not excuse the Commission from its statutory obligation to do what it can to apprise itselfand hence the public and the Congress - of the economic consequences of a proposed regulation before it decides whether to adopt the measure.” ${ }^{\text {,30 }}$ Thus, the court held that "the Commission violated its obligation under [the Investment Company Act], and therefore the APA, in failing adequately to consider the costs imposed upon funds by the two challenged conditions. ${ }^{31}$

Significantly, the D.C. Circuit in Chamber of Commerce faulted the SEC for its failure to consider, as suggested in dissents by two commissioners, disclosure of director independence in place of mandating independence. $^{32}$ The court, however, qualified this basis for faulting the SEC by characterizing the alternative of disclosure as "a familiar tool in the Commission's tool kit."33 On the other hand, the SEC obtained a potentially significant victory; the court quickly dismissed the Chamber's argument that the SEC was required either to develop new data to support its rule, or to fully consider each of the empirical studies before it as a result of the voluminous comments filed during the proposal process. ${ }^{34}$ Thus, the court concluded that the SEC is under no obligation to premise its rulemaking on empirical findings. ${ }^{35}$ The court also noted that the Commission's failure to

28. See id. at 143 ("With respect to the $75 \%$ independent director condition, the Commission ... claimed it was without a 'reliable basis for determining how funds would choose to satisfy the [condition] and therefore it [was] difficult to determine the costs associated with electing independent directors.' ... With respect to the costs of the independent chairman condition, counsel maintains the Commission 'was not aware of any costs associated with the hiring of staff because boards typically have this authority under state law, and the rule would not require them to hire employees.'” (citations omitted)).

29. Id. (emphasis added).

30. Id. at 144 .

31. Id. To support its conclusion, the court cited to a single case-its own decision in Public Citizen v. Federal Motor Carrier Safety Administration, 374 F.3d 1209 (D.C. Cir. 2004)—for the proposition that, even in the "face of uncertainty, [an] agency must 'exercise its expertise to make tough choices about which of the competing estimates is most plausible, and to hazard a guess as to which is correct, even if . . . the estimate will be imprecise." " Chamber of Commerce, 412 F.3d at 143 (quoting Pub. Citizen, 374 F.3d at 1221).

32. See Chamber of Commerce, 412 F.3d at 144 ("We conclude the Commission's failure to consider the disclosure alternative violated the APA.").

33. Id.

34. See id. at 142 (“[A]lthough we recognize that an agency acting upon the basis of empirical data may more readily be able to show it has satisfied its obligations under the APA, ... we are acutely aware that an agency need not-indeed cannot-base its every action upon empirical data ...." (citations omitted)).

35. See id. at 142-43 (holding that the Commission did not violate the APA by declining to conduct its own empirical study or by failing to closely consider a study offered to it via the noticeand-comment process, given that the SEC identified problems with the study). 
conduct its own empirical study of the potential costs of the proposed rule was not arbitrary and capricious, given that the Commission based its conclusion as to the benefits of the new rules on "its own and its staff's experience, the many comments received, and other evidence, in addition to the limited and conflicting empirical evidence.”36

In American Equity Investment Life Insurance Co. v. SEC, ${ }^{37}$ the D.C. Circuit was again asked to determine whether the SEC had satisfactorily considered whether newly adopted Rule 151A would promote efficiency, competition, and capital formation. ${ }^{38}$ The newly adopted rule disqualified fixed indexed annuities from falling within the definition of an annuity contract under Section 3(a)(8) of the Securities Act of $1933 .{ }^{39}$ An indexed annuity credits its purchaser with a rate of return based on the performance of an identified securities index, such as the Standard and Poor's Industrial 500 Index. $^{40}$ Pursuant to the newly minted Rule 151A, such annuities would no longer be exempt from the registration requirements of the Securities Act. ${ }^{41}$ Invoking the earlier Chamber of Commerce reasoning, American Equity argued that the costs of implementing Rule 151A were too burdensome and that imposing the additional regulation would be inefficient. ${ }^{42}$ In response, the SEC justified the change by reasoning that Rule 151A would "bring about clarity in what [had] been an uncertain area of law."43 The SEC thus believed reducing the uncertain status of indexed annuities was a benefit unto itself, further reasoning that the enhanced disclosures that would accompany the securities classification for this financial product would result in increased price transparency and market depth-each thereby favorably impacting efficiency, competition, and capital formation. ${ }^{44}$

The D.C. Circuit faulted the SEC's consideration of “competition."45 The court noted that while the SEC claimed to have analyzed Rule 151A's potential effects on competition, the Commission disclosed no reasoned basis for its conclusion. ${ }^{46}$ The court rejected the SEC's argument that the rule's adoption would "bring about clarity in ... an uncertain area of law" so that

36. Id. at 142 (quoting Investment Company Governance, 69 Fed. Reg. at 46,383).

37. 613 F.3d 166 (D.C. Cir. 2010).

38. Id. at 167.

39. Id. at $167-68$.

40. Id. at 168.

41. See id. at 167 ("As a result of this new rule, [fixed indexed annuities] are subject to the full panoply of requirements set forth by the Act ....”).

42. Id. at 177.

43. Id. (quoting Indexed Annuities and Certain Other Insurance Contracts, Securities Act Release No. 8996, Exchange Act Release No. 59,221, 74 Fed. Reg. 3138, 3171 (Jan. 16, 2009) (codified in part at 17 C.F.R. pt. 240)) (internal quotation marks omitted).

44. Id.

45. See id. ("We hold that the Commission's consideration of the effect of Rule 151A on ... competition ... was arbitrary and capricious.").

46. See id. ("The SEC purports to have analyzed the effect of the rule on competition, but does not disclose a reasoned basis for its conclusion that Rule 151A would increase competition.”). 
competition would be enhanced by encouraging more parties to enter the marketplace for fixed indexed annuities. ${ }^{47}$ The court concluded that this reasoning was flawed, reasoning that the SEC could adopt any rule-whether this one or a completely different one-and that act would necessarily bring about clarity. ${ }^{48}$ The mere fact that a rule might bring about "clarity" was not, in itself, "helpful in assessing the effect Rule 151A [would have] on competition." ${ }^{49}$ The court concluded that, at most, the SEC's reasoning would support the proposition that any new SEC rule in this area "could promote competition" by bringing about clarity in an uncertain legal field; however, this was not sufficient to show what effect the specific rule at issue, Rule 151A, would have on competition. ${ }^{50}$

The SEC further sought to justify new Rule 151A on the ground that it would increase competition because it "would require fuller public disclosure of [fixed indexed annuities] and thereby increase price transparency." ${ }^{21}$ The D.C. Circuit rejected this rationale, finding the SEC's competition analysis failed because the Commission "did not make any finding on the existing level of [price] competition in the marketplace under the state law regime" and thus "did not assess the baseline level of price transparency and information disclosure under state law." 52 As a result of this failure, "[t]he SEC could not accurately assess any potential increase or decrease in competition." 53 This basis for the D.C. Circuit's opinion is very similar to the bases invoked in Chamber of Commerce regarding the SEC's failure to consider state regulation as an alternative to the federal disclosure regime, as both disclosure and state regulation are "familiar tools" in the investor protection "tool kit." 54 With similar effect, the court concluded in American Equity that the SEC's analysis of the rule's impact on competition was "arbitrary and capricious because it failed to consider the extent of the existing competition in its analysis."55 The court, referencing its earlier holding in Chamber of Commerce, stated that by calling on the SEC to consider whether a rule would promote efficiency, competition, and capital formation, Congress imposed on "the SEC an obligation to consider the economic implications of certain rules it proposes." 56

47. Id. (citation omitted) (internal quotation marks omitted).

48. Id. at 177-78. As the court observed, the Review Standard did not call for the SEC to consider "whether any rule would have an effect on competition," but rather "whether the specific rule will promote efficiency, competition, and capital formation." Id. at 178 (emphasis in original).

49. Id.

50. Id.

51. Id.

52. Id. (emphasis added).

53. Id.

54. See Chamber of Commerce v. SEC, 412 F.3d 133, 144 (D.C. Cir. 2005) (characterizing disclosure as "a familiar tool in the Commission's tool kit").

55. 613 F.3d at 178.

56. Id. 
With respect to Rule 151A's impact on efficiency, the SEC's justification fared no better than its other arguments. In adopting Rule 151A, the SEC stated that increased price transparency would promote efficiency, arguing that the heightened disclosures flowing from registration as a consequence of Rule 151A would enable investors to make better-informed decisions in the investment-products marketplace. ${ }^{57}$ The court concluded that this analysis was insufficient because the SEC failed to consider whether, under existing regulations (principally those mandated by state law), investors were already able to make well-informed decisions. ${ }^{58}$ In other words, the SEC's reasoning was arbitrary and capricious because it failed "to analyze the efficiency of the existing state law regime."

Finally, the court concluded that the SEC's "capital formation" reasoning was arbitrary and capricious because the Commission's analysis of this factor depended heavily on its (allegedly) flawed assumption that Rule 151A's increased investor protections would increase market efficiency. ${ }^{60}$

\section{Congress and the Review Standard}

For most of its life, the principal governors on the SEC's rulemaking authority were the requirement that its rules be "necessary or appropriate in the public interest," and the need to consider whether the rule would advance the goal of "protection of investors." ${ }^{\prime}$ In 1996, Congress enacted the National Securities Markets Improvement Act of 1996 (NSMIA) and added the requirement that the SEC "also consider, in addition to the protection of investors, whether the action will promote efficiency, competition, and capital formation." ${ }^{2}$ In introducing the Review Standard, Congress left undefined the terms "consider," "efficiency," "competition," and "capital formation," and, far more importantly, did not explain what level of

57. Id. at $178-79$.

58. Id. at 179.

59. Id.

60. Id.

61. Although this combination of requirements was formally applied by statute to the SEC's general rulemaking authority in 1996, the provisions were applied to many of the SEC's rulemaking powers since the early years of the Commission. Compare National Securities Market Improvement Act of 1996, Pub. L. No. 104-290, § 106(b), 110 Stat. 3416, 3424 (1996) (codified at 15 U.S.C. $\S 77 b(b)$ (2006)) (applying this combination of requirements to the SEC's general rulemaking authority), with 15 U.S.C. § 79e(a) (Supp. IV 1938) (permitting the SEC, subject to those two restrictions, to utilize rules and regulations concerning the form of applications for registering as a holding company), and 15 U.S.C. § 79j(a) (Supp. I 1935) (permitting the SEC, subject to those two restrictions, to utilize rules and regulations regarding the form of applications for acquiring securities or capital assets).

62. National Securities Markets Improvement Act § 106. Oddly, NSMIA added the Review Standard only to the Securities Act of 1933 § 2(b), 15 U.S.C. § 77b(b) (2006), the Securities Exchange Act of 1934 § 3(f), 15 U.S.C. § 78c(f) (2006), and the Investment Company Act of 1940 $\S 2$ (c), 15 U.S.C. § 80a-2(c) (2006). In 1999, Congress added similar language to the Investment Advisers Act of 1940 § 202(c), 15 U.S.C. § 80b-2(c)(2006). Gramm-Leach-Bliley Act, Pub. L. No. 106-102, § 224, 113 Stat. 1338, 1402 (1999). 
consideration the SEC was required to give these items when engaged in rulemaking. ${ }^{63}$ Most of the focus of the legislative history was directed to the central substantive changes NSMIA introduced-namely, preempting much of the states' role in the registration of public offerings of securities. ${ }^{64}$ Nonetheless, insights into the breadth of the new requirement arise from the somewhat tortured path that the Review Standard traveled through the legislative process.

We believe the strongest indication of the level of assessment mandated by the Review Standard is what was initially adopted by the Senate but abandoned in conference with the House. The Senate's competing bill, Senate Bill 1815, required the SEC's Chief Economist to prepare a report on the potential consequences of a proposed regulation. ${ }^{65}$ The report would provide "an analysis of the likely effects of the proposed regulation on the economy of the United States, and particularly upon the securities markets and the participants in those markets." 66 The report was to contain "the estimated impact of the proposed regulation upon economic and market behavior, including any impact on market liquidity, the costs of investment, and the financial risks of investment., ${ }^{, 7}$ In the hearings on the bill, this provision enjoyed a cool reception. SEC Chairman Arthur Levitt believed the then-existing notice and comment procedure itself, without more, provided sufficient means to assess the burdens of any regulatory action; moreover, he argued against any assessment being made on a rule-by-rule basis, believing that the efforts of economists were "better directed toward analyzing the larger economic context and thematic issues that cut across markets" so that a market-by-market approach would be more useful. ${ }^{68}$ The only other testimony concerning the Senate's version cautioned that any review standard would be opposed if it placed undue burdens on the SEC. ${ }^{69}$ Nonetheless, the Senate bill retained this version of the review standard; indeed, the report accompanying the Senate's passage of the bill described its review standard as calling on the SEC to "demonstrate serious economic analysis throughout the process of developing regulations." ${ }^{\text {,70 }}$ At the same

63. National Securities Markets Improvement Act § 106.

64. See, e.g., 142 CONG. REC. E1928-29 (daily ed. Oct. 4, 1996) (speech of Rep. Thomas J. Bliley, Jr., Chairman, House Committee on Commerce) (discussing NSMIA's preemption of state authority over securities offerings and claiming disparate state laws hindered competition); H.R. REP. No. 104-864, at 39-40 (1996) (Conf. Rep.), reprinted in 1996 U.S.C.C.A.N. 3920, 3920-21 (discussing NSMIA's preemption of state authority concerning regulating securities offerings).

65. Securities Investment Promotion Act of 1996, S. 1815, 104th Cong. § 310(b)(1) (1996).

66. Id. § 310(b)(2)(A).

67. Id. § 310(b)(2)(B).

68. The Securities Investment Promotion Act of 1996: Hearing on S. 1815 Before S. Comm. on Banking, Hous., and Urban Affairs, 104th Cong. 47 (1996) (statement of Arthur Levitt, Chairman, U.S. Sec. \& Exch. Comm'n).

69. Id. at 147 (statement of Paul Saltzman, Senior Vice President and General Counsel, Public Securities Association).

70. S. REP. NO. 104-293, at 16 (1996). 
time, the overall thrust of the bill was, according to the report, that of achieving better balance between investor protection and the cost of investing through the preemption of much of the state regulation of public offerings. $^{71}$

The Senate's review language disappeared in the conference convened to reconcile the differences between the House and Senate bills; ${ }^{72}$ the original language of the House bill carried the day and became law as part of NSMIA. ${ }^{73}$ The conferees apparently preferred the House's loosely worded, indefinite language to the more precise, quantitatively driven approach approved by the Senate. Most importantly, in rejecting the Senate's approach, the conferees also rejected a cost-benefit assessment for each proposed SEC rule. At the same time, it is not clear from the rest of the scant legislative history just how the SEC's rulemaking practices were to be changed by the NSMIA, if at all, from what the practices were before.

The Report accompanying the House's version of NSMIA sheds modest light on the content of the Review Standard. First, it expresses an expectation that " $t]$ he Committee expects that the Commission will engage in rigorous analysis pursuant to this section." when considering efficiency, competition, and capital formation, "the Commission shall analyze the potential costs and benefits of any rulemaking initiative, including, whenever practicable, specific analysis of such costs and benefits." 75

While this language suggests more, indeed much more, would be required of the SEC in rulemaking than was the prior practice, a contemporary neutral assessment of the provision by the Congressional Budget Office concluded that "[b]ecause the SEC currently conducts costbenefit analyses in conjunction with its rulemakings," "76 the "CBO would not expect this provision to result in any additional costs to the federal government." 77

Moreover, the House Report states that "[t]he legislation also seeks to promote efficiency, competition, and capital formation in the capital markets without compromising investor protection by ... requiring the consideration of efficiency, competition, and capital formation whenever the Securities and Exchange Commission ... makes a public interest determination in its

71. See id. at 2 (summarizing the report to follow).

72. Compare H.R. REP. No. 104-864, at 27 (1996) (Conf. Rep.) with Securities Investment Promotion Act of 1996, S. 1815, 104th Cong. § 310(b) (1996).

73. Compare Securities Amendments of 1996, H.R. 3005, 104th Cong. (as passed by House, June 19, 1996) with H.R. REP. No. 104-864, at 10 and National Securities Market Improvement Act of 1996, Pub. L. No. 104-290, § 106, 110 Stat. 3416, 3424 (1996) (codified at 15 U.S.C. §§ 77b, 78c(f), 80a-2(c) (2006)).

74. H.R. REP. NO. 104-622, at 39 (1996) (emphasis added).

75. Id.

76. Id. at 24 .

77. Id. 
rulemaking."78 The report further adds that the triple considerations of efficiency, competition, and capital formation were to be "consistent with the public interest and investor protection.,79

Thus while inviting "rigorous analysis" by the SEC per the Review Standard, the House Report also stated that for the life of the SEC, "the foremost mission of the Commission has been investor protection, and this section does not alter the Commission's mission.",80

Further, there is significant circumstantial evidence suggesting that Congress must not have intended the Review Standard to be especially demanding on the SEC. Looking just at the language of the statute, the operative verb in the Review Standard is "consider": the Review Standard does not require the SEC to "determine" whether a rule will actually promote efficiency, competition, or capital formation. In fact, Congress included a "determination" requirement in the first draft of the provision, then removed it in subsequent versions. ${ }^{81}$

The contemporary meaning of "consider" suggests that if, after "considering" whether a proposed rule would "promote efficiency, competition, and capital formation," the SEC concludes that it would not promote those goals, the Review Standard does not require the SEC to abandon the rule. Indeed, the plain import of the Review Standard is that it does not require the SEC to come to a conclusion about a proposed rule's effect on efficiency, competition, and capital formation; it does not prevent adoption of a rule because of indeterminacy of the rule's impact. For that matter, the plain language of the Review Standard does not require the SEC to state a strong reason why a rule should be passed even if, upon consideration, it appears the rule would not promote efficiency, competition, or capital formation.

Nowhere in the legislative history did any member of Congress ever specify, or even suggest, exactly how the SEC should go about "considering" the enumerated factors, nor did any member ever specify exactly what aspect of "efficiency," "competition," or "capital formation" the SEC should consider. (For example, does "efficiency" mean "efficiency of the capital markets"? How is that distinct from "competition"? What if a proposed rule might promote "efficiency," but not promote "capital formation"? The legislative history leaves these questions unanswered.) What is stated in the legislative history is that the SEC's “consideration" is to entail rigorous analysis and evaluation of the potential costs and benefits of the proposed rule. $^{82}$ This is not the same as mandating that the rule must be justified

78. Id. at 16 (emphasis added).

79. Id. at 38 .

80. Id. at 39 (emphasis added).

81. See H.R. 2131, 104th Cong. § 8(b) (1995) (requiring the SEC to consider or determine whether an action will "promote efficiency, competition, and capital formation").

82. See supra notes 74-75 and accompanying text. 
because it meets each of the considerations of efficiency, competition, and capital formation, or requiring that the rule, in the language of Business Roundtable, yield a net benefit. ${ }^{83}$

Further evidence that Congress did not intend the Review Standard to impose significant changes in the criteria by which to judge SEC rulemaking occurred in 1999 when Congress added the Review Standard to the Investment Advisers Act. ${ }^{84}$ Interestingly, this apparent oversight was corrected through a conforming amendment to the much more significant Gramm-Leach-Bliley Act, ${ }^{85}$ which repealed the Glass-Steagall Act, the cornerstone of financial regulation since the Great Depression. ${ }^{86}$ Thus, the primary thrust of the legislative effort was to overhaul regulation of the financial services industry and not to update SEC rulemaking procedures. ${ }^{87}$ In the conference report accompanying the bill, the conferees rebuked the SEC for not doing a satisfactory job in implementing the Review Standard earlier enacted in the NSMIA. ${ }^{88}$ However, the conferees gave no specific examples of the failures causing their unhappiness; ${ }^{89}$ hence, their rebuke appears hollow, as Congress later added the same Review Standard the conferees were complaining about to the Investment Advisers Act. Despite many hearing appearances by SEC Chairman Levitt and staff members in connection with the 1999 legislation, ${ }^{90}$ the hearings and other portions of the legislative history of the 1999 legislation are devoid of any reports on the SEC's discharge or noncompliance with the Review Standard. In the end, the same Review Standard as earlier enacted in NSMIA was included in the Investment Advisers Act.

As seen from the above, the legislative history of the Review Standard is far from conclusive or clear on the intensity of the review mandated by the NSMIA. On the one hand, there is evidence from the House Commerce Committee's report stating the Committee's expectation that the SEC would engage in "rigorous analysis," and that the SEC would quantify and analyze with specificity the costs and benefits of a proposed rule. ${ }^{91}$ Further, when the

83. Bus. Roundtable v. SEC, 647 F.3d 1144, 1153 (D.C. Cir. 2011).

84. Gramm-Leach-Bliley Act, Pub. L. No. 106-12, § 224, 113 Stat. 1338, 1402 (codified at 15 U.S.C. $\S 80 b-2(c)$ (2006)) (incorporating the Review Standard into $\S 202$ of the Investment Advisers Act).

85. Id.

86. RICHARD SCOTT CARNELL ET AL., THE LAW OF BANKING AND FINANCIAL INSTITUTIONS 18 (4th ed. 2009) (calling the Glass-Steagall Act a "centerpiece of American banking policy" between its enactment in 1933 and its later repeal).

87. See Kenneth R. Benson et al., Financial Services Modernization: GrahamLEACH-BLILEY ACT OF 1999, LAW AND EXPLANATION 3, 21 (1999) (summarizing the main purposes of the Graham-Leach-Bliley Act, none of which include updating SEC rulemaking procedures).

88. H.R. REP. No. 106-434, at 165 (1999) (Conf. Rep.).

89. See id. at $164-65$.

90. H.R. REP. No. 106-74, pt. 3, at 120 (1999).

91. See supra notes 74-75 and accompanying text. 
House was considering adopting the Conference Report, House Commerce Committee Chairman Bliley stated (erroneously) that the provision would "require the SEC to conduct meaningful cost-benefit analysis of proposed" rules. $^{92}$ In the Conference Report for the Gramm-Leach-Bliley Act, the conferees claimed disappointment with SEC compliance with the new provisions. $^{93}$ And, many witnesses in the House subcommittee hearings on the NSMIA's precursor testified to their belief that more serious SEC consideration should be statutorily required in the rulemaking context. ${ }^{94}$

Perhaps most enlightening is Congress's failure to act even when it claimed dissatisfaction with how the SEC implemented the NSMIA. When it added the "promote efficiency" consideration requirements to the Investment Advisers Act, Congress had an opportunity to hold hearings in which it could criticize the SEC's implementation of the NSMIA. It did not do so. Congress also had the opportunity to modify the language added to the Investment Advisers Act and to modify the language in the other statutes. Instead, it chose to use the same language once again. ${ }^{95}$

Further insight into the level of assessment Congress imposed on the SEC through the Review Standard is suggested by Congress's enactment of an amendment, also as part of the Gramm-Leach-Bliley Act, that set forth a very different review standard for rules promulgated by the Commodity Futures Trading Commission (CFTC). ${ }^{96}$ That standard called on the CFTC to "consider the costs and benefits of the action" and provided that " $\mathrm{t}$ ]he costs and benefits ... shall be evaluated in light of . . . considerations of the efficiency, competitiveness, and financial integrity of futures markets." ${ }^{\text {,7 }}$

The very different language used for the CFTC-namely, the express call for the CFTC to "consider the costs and benefits" of rules, as well as the clear implication of Congress's embracement of a more demanding standard for the CFTC than for the SEC-further supports the view that Congress, when it wished for costs and benefits to be assessed, certainly knew how to impose that requirement for an agency's rulemaking. Moreover, the fact that

92. 142 CONG. REC. 25,810 (1996) (statement of Rep. Thomas Bliley).

93. H.R. REP. NO. 106-434, at 165.

94. See H.R. REP. NO. 104-622, at 16 (describing the witness testimony before the subcommittee as indicating a need for modernization of the SEC's regulatory scheme to avoid inefficient, costly, and duplicitous rules that fail to adequately protect investors).

95. Compare Gramm-Leach-Bliley Act, Pub. L. 106-102, § 224, 113 Stat. 1338, 1402 (1999) (codified at 15 U.S.C. § 80b-2(c) (2006)) with National Securities Market Improvement Act of 1996, Pub. L. No. 104-290, § 106(a), 110 Stat. 3416, 3424 (1996) (codified at 15 U.S.C. § 77b(b) (2006)).

96. S. 257, 105th Cong. § 11 (as introduced on Feb. 4, 1997).

97. H.R. 5660, 106th Cong. § 119 (2000) (codified at 7 U.S.C. § 19(a) (2006)) (enacted by incorporation by reference in the Consolidated Appropriations Act of 2001, Pub. L. No. 106-554, $\S 1(a)(5), 114$ Stat. 2763, 2763 (2000)). The only reference in the legislative history to this change states generally that the standard calls on the CFTC to consider costs and benefits of its actions and that the standard does not apply to investigative or emergency actions. H.R. REP. NO. 106-711, pt. 1, at 40 (2000); H.R. REP. No. 106-711, pt. 3, at 59 (2000); S. REP. No. 106-390, at 13 (2000). 
Congress imposed the more demanding language on the CFTC at the same time that it extended the earlier NSMIA standard to the Investment Advisers Act suggests not only a consciousness that the two agencies operated under different standards, but also that Congress knew how to express a more demanding standard when it wanted to do so and therefore suggests that Congress consciously chose to impose two very different standards on the agencies. As seen earlier, the NSMIA conferees rejected and eliminated the requirement, found in Senate Bill 1815, that the SEC Chief Economist prepare a report on the economic consequences of a proposed ruleincluding its effect on the market and market participants-and publish that report before adopting the rule. ${ }^{98}$ Had the Congress that enacted GrammLeach-Bliley truly wanted the SEC to do more in compliance with the Review Standard, it could have amended the Review Standard's requirements to be on more of a scale of Senate Bill 1815; it did not. And, despite House Report 104-622 and Representative Bliley's statements to the contrary, the Review Standard (that is, the language Congress actually adopted) does not explicitly require the SEC to specify the costs of any proposed rule, to engage in rigorous analysis, or even to engage in costbenefit analysis.

Given this conflict in the legislative history, and given that the purpose of the enacting legislation was primarily to modify the allocation of responsibilities between federal and state regulatory entities (or, in the case of the provisions added to the Investment Advisers Act, to repeal GlassSteagall), it seems unlikely that the Review Standard was truly designed to establish more than a thoughtful analysis of the proposed rule's potential effects. Certainly, it was not designed to require the SEC to conclude, as Business Roundtable states, that the rule yields a "net benefit." "99

III. Outside the Shadow of Precedent

\section{A. The Supreme Court's Tapestry for Judicial Review}

The leading authority for judicial review of agency action is Chevron U.S.A. Inc. v. NRDC, ${ }^{100}$ which embraces a two-step analysis. ${ }^{101}$ Step one asks whether the agency had the authority to act, and step two considers whether the agency permissibly exercised the authority Congress granted it. $^{102}$ It is under this latter step that the Administrative Procedure Act (APA) enters the scene. Under the APA, a court can invalidate an agency-made rule

98. See supra notes 65-72 and accompanying text.

99. Bus. Roundtable v. SEC, 647 F.3d 1144, 1153 (D.C. Cir. 2011).

100. 467 U.S. 837 (1984).

101. See id. at 843 (describing the two steps required by the newly minted analysis).

102. See id. at 842-43 ("Rather, if the statute is silent or ambiguous with respect to [a] specific issue, the question for the court is whether the agency's answer is based on a permissible construction of the statute.”). 
if it concludes the rule is "arbitrary, capricious, an abuse of discretion, or otherwise not in accordance with law."103 "Hard look" review has become the name of the game: courts subject an agency's rule to rather rigorous analysis to ensure the rule is the product of reasoned decisionmaking - that the rule is a product of sound reason rather than being "arbitrary and capricious."104 The Supreme Court famously generalized this test in Motor Vehicle Manufacturers Ass'n v. State Farm Mutual Automobile Insurance Co. ${ }^{105}$ :

Normally, an agency rule would be arbitrary and capricious if the agency has relied on factors which Congress has not intended it to consider, entirely failed to consider an important aspect of the problem, offered an explanation for its decision that runs counter to the evidence before the agency, or is so implausible that it could not be ascribed to a difference in view or the product of agency expertise. $^{106}$

Thus, the quality and coherence of the agency's reasoning is the focus of judicial review under hard look. And this makes sense; as noted by one commentator on administrative law, the hard look requirement helps courts ensure that an agency is not exceeding its mandate or the bounds of its statutory authority with a particular rule. ${ }^{107}$

While the agency's reasoning is fair game under hard look review, the specific procedures that the agency uses to arrive at its final rule are not. In Vermont Yankee Nuclear Power Corp. v. NRDC ${ }^{108}$ the Court struck down the D.C. Circuit's attempt to require an agency to satisfy extra-statutory procedural requirements before enacting a new rule. ${ }^{109}$ The Court tempered its ruling by stating, "[t]his is not to say necessarily that there are no circumstances which would ever justify a court in overturning agency action because of a failure to employ procedures beyond those required by the statute," but the Court ultimately concluded, "such circumstances, if they exist, are extremely rare."110 First enunciated in the context of agency adjudication, the rule from Vermont Yankee had a dramatic effect on judicial review of agency rulemaking, stopping courts from imposing extra-statutory

103. Administrative Procedures Act, 5 U.S.C. § 706(2)(A) (2006).

104. See 1 RiCHARD J. PiERCE, JR., AdMinistrative LAW TREATISE § 7.4, at 599-600 (5th ed. 2010) (arguing that State Farm's reasoned decisionmaking requirement forces agencies to discuss all major considerations it took into account in formulating a new, major rule to demonstrate that its rule meets the reasoned decisionmaking requirement).

105. 463 U.S. 29 (1983).

106. Id. at 43 .

107. PIERCE, supra note 104, § 7.4, at 599.

108. 435 U.S. 519 (1978).

109. Id. at 525 .

110. Id. at 524; see also Pension Benefit Guar. Corp. v. LTV Corp., 496 U.S. 633 (1990) (reaffirming this principle in the context of informal agency adjudications). 
procedural requirements on agencies. ${ }^{111}$ Thus, when reviewing an agencymade rule, courts must confine themselves to the requirements that actually appear in the agency's organic statute (and any other relevant statutes) and not attempt to add any extra-statutory procedures to satisfy their own sense of what the agency should, or should not, be doing. ${ }^{112}$

\section{B. "Mirror, Mirror, on the Wall"}

In its decisions applying the Review Standard, the precedent most heavily relied upon by the D.C. Circuit was not that of the Supreme Court but the D.C. Circuit's own earlier decisions. Business Roundtable and American Equity both cite almost exclusively to Chamber of Commerce (at least with regard to how to interpret the Review Standard), and Chamber of Commerce in turn relied on the D.C. Circuit's own decision in Public Citizen v. Federal Motor Carrier Safety Administration. ${ }^{113}$ There, the court reviewed a regulation that limited the number of hours commercial drivers could work. ${ }^{114}$ The court held that the regulation was arbitrary and capricious-but for reasons we find to be completely inapposite here. There, as here, the basis of the decision was that the agency had failed to satisfy the requirements of its organic statute. ${ }^{115}$ However, the review standard at issue in Public Citizen is completely unlike the Review Standard applicable to the SEC; that statute actually requires the Federal Motor Carrier Safety Administration (FMCSA) to "ensure" that the rule will have the effect of promoting a specific factor. ${ }^{116}$ The Public Citizen court vacated the rule at issue because not only had the agency failed to ensure that the rule would promote that factor-it hadn't even discussed it in its adopting release. ${ }^{117}$ Thus, "[b]ecause the agency ... wholly failed to comply with this specific statutory requirement," the court vacated the agency's rule. ${ }^{118}$ The court

111. PIERCE, supra note 104, § 7.8, at 661.

112. See Vt. Yankee, 435 U.S. at 543 ("Absent constitutional constraints or extremely compelling circumstances the administrative agencies should be free to fashion their own rules of procedure and to pursue methods of inquiry capable of permitting them to discharge their multitudinous duties.” (citations omitted) (internal quotation marks omitted)).

113. 374 F.3d 1209 (D.C. Cir. 2004).

114. Id. at 1214-16.

115. Id. at 1216 .

116. See id. (citing 49 U.S.C. § 31136(a)(4) (2006)). The agency’s organic statute, the Motor Carrier Safety Act, stated that "[a]t a minimum, the regulations [promulgated by the agency] shall ensure that ... the operation of commercial motor vehicles does not have a deleterious effect on the physical condition of the operators.” 49 U.S.C. § 31136(a)(4) (2006) (emphasis added).

117. See Pub. Citizen, 374 F.3d at 1217 (requiring the agency to explain its justification for the new rule and vacating the judgment due to the agency's failure to consider or discuss the required statutory factor when it issued its new rule).

118. Id. at 1216. 
needed no further basis on which to invalidate the rule, so it provided no further holdings on the matter. ${ }^{119}$

We emphasize that the actual holding of Public Citizen has nothing to do with cost-benefit analysis - it was that the agency had failed to live up to the standards in its own statute that it ensure a certain outcome from its rule. $^{120}$ But the court did opine-albeit in dicta—on the possible infirmities of the agency's cost-benefit analysis. Of particular note is that the statute in Public Citizen explicitly required the agency to "consider the costs and benefits" of a proposed rule. ${ }^{121}$ Thus, the Public Citizen court stood on firm ground when it opined that the agency had fallen short of its statutory duties. (The agency there concluded that cost estimates "vary enormously" and thus refrained from trying to quantify them; it didn't even bother to give an excuse for its failure to estimate the rule's potential benefits.) ${ }^{122}$ In other words, the actual holding of Public Citizen had nothing to do with the agency's alleged failure to consider costs, much less with its failure to consider that (or any other) factor.

Yet, despite the difference, Chamber of Commerce used Public Citizen as the lens through which it assessed the SEC's satisfaction of the Review Standard. The court cites Public Citizen fourteen times in its opinion. For example, Chamber of Commerce invoked Public Citizen for the proposition that, even if an agency faces uncertainty over the costs of a proposed rule, the agency has a "statutory obligation to determine as best it can the economic implications of the rule it has proposed" $" 123$ and it must "exercise its expertise to make tough choices about which of the competing estimates is most plausible, and to hazard a guess as to which is correct, even if ... the estimate will be imprecise." 124 But in doing so the court failed to note that the review standard at issue in Public Citizen called on the regulatory agency "[at] a minimum ... [to] ensure that ... the operation of commercial motor vehicles does not have a deleterious effect on the physical condition of the operators."125 Moreover, the statute under which the FMCSA had acted

119. See id. ("Several of petitioners' other objections also raise troubling concerns about the [agency's] decisionmaking process. We do not, however, enter final judgment on those, as we are vacating and remanding the matter in any case ....").

120. Id.

121. Id. at 1221 (citing 49 U.S.C. § 31506(d) (2006)). For other examples of Congress directing those charged with implementing the statute to consider the costs and benefits to any new regulations or requirements, see also 49 U.S.C. § 31136(c)(2)(A) (2006) and 49 U.S.C. § 31502(d) (2006).

122. Pub. Citizen, 374 F.3d at 1221-22.

123. Chamber of Commerce v. SEC, 412 F.3d 133, 143 (D.C. Cir. 2005) (citing Pub. Citizen, 374 F.3d at 1221).

124. Id. (quoting Pub. Citizen, 374 F.3d at 1221) (internal quotation marks omitted). The language from Public Citizen, quoted by the Chamber of Commerce court, was itself dicta. The Public Citizen court declined to "enter [a] final judgment on" the failure to quantify and consider costs of a proposed rule, but stated it was including the discussion of this point merely "for a sense of completeness.” Pub. Citizen, 374 F.3d at 1216-17.

125. Pub. Citizen, 374 F.3d at 1212 (emphasis added). 
expressly required that the "Secretary shall consider the costs and benefits of the requirement." 126 Thus, not only was formal cost-benefit analysis expressly called for by Congress, but the Secretary was under the further mandate to "ensure" that the proposed rule did not have a deleterious effect. Each of these components of the review standard was at the heart of Public Citizen, but light-years from the Review Standard applicable to the SEC. As seen, the SEC is not called upon under its Review Standard to either engage in cost-benefit analysis or to ensure that competition, efficiency, or capital formation are favorably impacted as a result of the rule. In sum, Chamber of Commerce rested its analysis and conclusions on the dicta arising from a case where the regulatory agency was operating under a markedly different review standard. One can speculate, therefore, whether the mixing of apples and oranges yields only a lemon.

Business Roundtable made limited reference to Public Citizen; nonetheless, it relied almost exclusively on Chamber of Commerce, particularly those passages of Chamber of Commerce that rested on Public Citizen. While courts can be expected to rely on their own precedents, such reliance is mischievous when the precedents are inapposite, as was Public Citizen to the issues before the court in Chamber of Commerce and Business Roundtable.

\section{Defying the Supreme Court-Usurping Congress}

A close analysis of the D.C. Circuit's decisions in Chamber of Commerce and Business Roundtable reflects stunning disconnects. As seen in Part II, while the D.C. Circuit's opinions repeatedly call for cost-benefit analysis, this is not the standard that Congress prescribed. Indeed, neither case involved, as did American Equity, the question of what role efficiency, competition, and capital formation should play in the review process. Most significantly, the D.C. Circuit engages in the ultimate disconnect-namely, being outside the precedent, reviewed above, developed by the Supreme Court for judicial review of actions by administrative agencies. Through its single-minded focus on cost-benefit analysis, the ultimate effect of the Chamber of Commerce and Business Roundtable decisions appears to be nothing less than establishing a new review standard. If this surmise is correct-and we believe it can hardly be otherwise-then each of these decisions violates the simple, clear holding of the Supreme Court that the "circumstances which would ever justify a court in overturning agency action because of a failure to employ procedures beyond those required by the

126. 49 U.S.C. § 31502(d) (2006) (emphasis added); see also id. § 31136(c)(2) (“Before prescribing regulations under this section, the Secretary shall consider, to the extent practicable[,] ... costs and benefits ....”). 
statute[,] . . . if they exist, are extremely rare.”"27 As a leading commentator has observed, this principle, first established in Vermont Yankee, has had a dramatic effect on judicial review of agency rulemaking, stopping courts from imposing extra-statutory procedural requirements on agencies. ${ }^{128}$

The incongruity of Chamber of Commerce and Business Roundtable with Vermont Yankee is even sharper when considered against American Textile Manufacturers Institute, Inc. v. Donovan, ${ }^{129}$ where the Supreme Court observed that "Congress uses specific language when intending that an agency engage in cost-benefit analysis." 130 The Supreme Court then cited to numerous statutory examples where Congress had so expressed its intentions in clear and unambiguous language, using the phrase itself or mentioning "costs" in relation to some other stated objective, or simply using terms like "feasible." 131 Thus, the Supreme Court concluded that the absence of such clear verbiage means that the reviewing court cannot compel the agency to engage in cost-benefit analysis. ${ }^{132}$

American Equity ${ }^{133}$ stands on quite different footing than either Chamber of Commerce or Business Roundtable. In American Equity, Chief Judge Sentelle-who also authored Public Citizen - confined the court's analysis to a review of the section of the adopting release that actually dealt with "efficiency, competition, and capital formation." 134 Rather than focusing on costs and benefits, he emphasized the overall incompleteness of the rule's supporting analysis. ${ }^{135}$ In this way, the analysis in American Equity differed greatly from that in Chamber of Commerce and Business Roundtable.

127. Vt. Yankee Nuclear Power Corp. v. NRDC, 435 U.S. 519, 524 (1978); see also Pension Benefit Guar. Corp. v. LTV Corp., 496 U.S. 633, 644-46 (1990) (reaffirming this principle in the context of informal agency adjudications).

128. PIERCE, supra note $104, \S 7.8$, at 661.

129. 452 U.S. 490 (1981).

130. Id. at 510-11. American Textile is a natural extension of Vermont Yankee, since if the reviewing court cannot impose a standard other than that adopted by Congress, the reviewing court cannot impose cost-benefit analysis where Congress has stated another review standard.

131. Id. at 510-12, 510 n.30. One such example the Court referenced was where the statute requires the agency to use "the best available and safest technologies..., except where the Secretary determines that the incremental benefits are clearly insufficient to justify the incremental costs.” Id. at 510 (emphasis omitted).

132. Id. at 512; see Entergy Corp. v. Riverkeeper, Inc., 129 S. Ct. 1498, 1508 (2009) (stating that in American Textile the agency did not need to "engage in cost-benefit analysis," in part because the statute did not contain such a requirement).

133. American Equity was originally decided in 2009. See Am. Equity Inv. Life Ins. Co. v. SEC, 572 F.3d 923, 936 (D.C. Cir. 2009) (remanding and requiring the SEC to "either complete an analysis sufficient to satisfy its obligations under $\S 2$ (b) [of the Securities Act], or explain why that section does not govern this rulemaking”), amended and superseded, 613 F.3d 166, 179 (D.C. Cir. 2010). The opinion was reissued with amendments in 2010 to reflect the Court's decision that vacating the SEC rule was the appropriate remedy. Am. Equity Inv. Life Ins. Co. v. SEC, 613 F.3d 166 (D.C. Cir. 2010).

134. Am. Equity, 613 F.3d at 176-79.

135. Id. at 177-79. 
And arguably, the court did a better job of adhering to the hard-look standards from State Farm and (more generally) the APA by focusing on the quality of the reasoning that the SEC actually did when it promulgated Rule 151A. In State Farm the Court held that an agency must provide a "satisfactory explanation for its action." 136 And in American Equity, the court focused on each of the SEC's serial conclusions that Rule 151A would in fact favorably impact "efficiency," "competition," and "capital formation." 137 Because the SEC's analysis in support of those conclusions fell so woefully short of being convincing, the D.C. Circuit held that the SEC's adoption of the rule was arbitrary and capricious. Simply stated, the SEC failed to provide a reasoned explanation for the rule it adopted, at least against readily available alternatives. (Indeed, even if the SEC had not gone so far as to conclude that Rule 151A would favorably impact efficiency, competition, and capital formation, the incompleteness in the SEC's reasoning seems to us to be so great that the result would not have changed.) We therefore believe the American Equity panel stood on firm ground, ground sowed by State Farm, because the court there assessed the quality of the reasoning the SEC employed in its efficiency, competition, and capital formation analysis.

\section{Has the SEC Repeatedly Shot Itself in the Foot?}

We might still question whether the American Equity court nonetheless overstepped the limits of judicial review by failing to judge the SEC's performance per the terms of the Review Standard: after all, the court focused on whether the SEC had properly concluded that Rule 151A would actually promote efficiency, competition, and capital formation, rather than just asking whether the SEC has adequately considered the question. As seen, the Review Standard asks only that the SEC consider whether the proposed rule will promote those factors. It doesn't require the SEC to ensure or otherwise conclude that the factors will be promoted. Nor does it require the SEC to ensure (or even conclude) that the proposed rule will have the net effect of promoting those factors (rather than having the effect of promoting those factors in some way, but the net effect being one of not promoting them). Nor does it specify the universe of data that it must consider - and this point differentiates the Review Standard from, say, other laws (like the one at issue in State Farm) that specifically require the agency

136. Motor Vehicle Mfrs. Ass’n v. State Farm Mut. Auto. Ins. Co., 463 U.S. 29, 43 (1983).

137. See Am. Equity, 613 F.3d at 177 (discussing how the SEC’s § 2(b) analysis regarding "competition" failed because the Commission "d[id] not disclose a reasoned basis for its conclusion that Rule 151A would increase competition" (emphasis added)); id. at 179 ("The SEC's failure to analyze the efficiency of the existing state law regime renders arbitrary and capricious the SEC's judgment that applying federal securities law would increase efficiency.” (emphasis added)). 
to consider a particular set of data or research, and to take those into consideration when promulgating a rule. ${ }^{138}$

In American Equity, the court simply circumnavigated these issues by focusing on what the SEC actually purported to do; the SEC's adopting release reached conclusions regarding the favorable effects Rule 151A would have on efficiency, competition, and capital formation. ${ }^{139}$ We might well wonder what the result would have been had the SEC instead merely explored the possible effects, pro and con, on each of the review factors. But the SEC instead affirmatively found that Rule 151A would enhance efficiency, competition, and capital formation. By doing this, it fell into State Farm's talons. In State Farm, the agency was under no express statutory obligation to weigh the rule's potential costs and benefits. ${ }^{140}$ Yet, the agency did so anyway. ${ }^{141}$ The Supreme Court proceeded to assess the agency's actions on the agency's own terms. Having found the cost-benefit analysis incomplete, the Court concluded the agency had acted arbitrarily and capriciously in adopting the rule since it failed to provide a "reasoned analysis" for its action. ${ }^{142}$

Similar to State Farm, the D.C. Circuit's decisions in Chamber of Commerce and Business Roundtable can be seen as instances where the agency justifies its rule by an approach not directly implicated by the Review Standard, namely reviewing the costs and benefits of the rule it adopts. For example, in the rulemaking reviewed in Chamber of Commerce the SEC provided close analysis of the impact of the proposed changes in governance rules on efficiency, competition, and capital formation in Part VIII of the adopting release, and in Part VI of the release, it estimated the costs and benefits of the new rule. ${ }^{143}$ Most striking is that the SEC in adopting the new independence rules focused its attention on the reasoning advanced in the

138. See State Farm, 463 U.S. at 33, 43 (articulating the requirement under the National Traffic and Motor Vehicle Safety Act of 1966 that the Secretary of Transportation "consider 'relevant available motor vehicle safety data"" and "articulate a satisfactory explanation for its action including a 'rational connection between the facts found and the choice made'" (citations omitted)).

139. Am. Equity, 613 F.3d at 176-79; Indexed Annuities and Certain Other Insurance Contracts, Securities Act Release No. 8996, Exchange Act Release No. 59,221, 74 Fed. Reg. 3138, 3169-72 (Jan. 16, 2009) (codified in part at 17 C.F.R. pt. 240).

140. State Farm, 463 U.S. at 33-34 (articulating the statutory requirement that the NHTSA "consider ... whether the proposed standard 'is reasonable, practicable and appropriate"” and "the 'extent to which such standards will contribute to carrying out the purposes' of the [National Traffic and Motor Vehicle Safety Act of 1966]"). In assessing the cost-benefit analysis engaged in by the NHTSA, the court remarked that "[t]he agency's obligation is to articulate a 'rational connection between the facts found and the choice made."” Id. at 59 .

141. Id. at 54-55.

142. Id. at 57.

143. Investment Company Governance, Investment Company Act Release No. 26,520, 69 Fed. Reg. 46,378, 46,386-87, 46,388-89 (Aug. 2, 2004) (codified at 17 C.F.R. pt. 270); see Chamber of Commerce v. SEC, 412 F.3d 133, 144 (D.C. Cir. 2005) (finding that even if there is uncertainty as to the effects of a proposed rule on efficiency, competition, capital formation, or costs this does not excuse the SEC from its statutory obligation to consider the economic consequences of a proposed regulation). 
latter and not the former. While this might appear totally consistent with State Farm, we believe there is an important, albeit nuanced, difference. Chamber of Commerce does not, as did State Farm, merely hold the agency failed to provide a reasoned basis through the use of cost-benefit analysisbut expressly held that the cost-benefit approach underlaid the Review Standard. ${ }^{144}$ Had Chamber of Commerce instead more narrowly limited its holding, the court's approach would have been closer to the firm ground of State Farm. However, the message remains: had the SEC eschewed proffering a conclusion premised on cost-benefit analysis, it would have (under available Supreme Court precedent) been in a much better place for limiting the scope of judicial review.

There is yet another force lurking in the background. Cost-benefit analysis of agency actions is regularly undertaken by the Office of Management and Budget through its Office of Information and Regulatory Affairs (OIRA). ${ }^{145}$ However, independent regulatory agencies, such as the SEC, have not been subject to OIRA reviews, reflecting the constitutional uncertainty surrounding whether the executive branch can interdict activities carried out by an agency pursuant to congressionally enacted standards and mandates. $^{146}$

It is intriguing to speculate whether the SEC's rules would meet with more success if subject to OIRA review rather than the newly established activism of the D.C. Circuit. ${ }^{147}$ Equally ponderous is whether the D.C.

144. See Chamber of Commerce, 412 F.3d at 144 (holding that the SEC violated the APA when it failed to consider the costs of two conditions in its proposed regulations).

145. The Office of Information and Regulatory Affairs (OIRA) is the product of the Paper Reduction Act of 1980. About OIRA, WhITE HOUSE, OfFICE MgMT. \& Budget, http://www.whitehouse.gov/omb/inforeg_administrator. President Reagan soon mobilized the office to undertake cost-benefit analysis of non-independent regulatory agencies through Executive Order 12,291. Exec. Order No. 12,291, 3 C.F.R. 127 (1981); see Thomas O. McGarity, Presidential Control of Regulatory Agency Decisionmaking, 36 AM. U. L. REV. 443, 478 \& n.171 (1987) (discussing presidential efforts to increase agency accountability through the use of executive orders).

146. See Robert W. Hahn \& Cass R. Sunstein, A New Executive Order for Improving Federal Regulation? Deeper and Wider Cost-Benefit Analysis, 150 U. PA. L. REV. 1489, 1506 (2002) (stating that President Reagan considered, but declined, subjecting independent agencies to these reviews).

147. OIRA and review by a federal appellate court, however, are not mirror images of one another. While the appellate court can be expected to have a point of view, it is less likely to be swayed by external influence than OIRA. Indeed, there is a good deal of information surrounding the conduct and outcomes of OIRA review that calls into question the detachment with which costs and benefits were assessed. There is every reason to fear that the independence of the review process within the executive branch of government is not likely to be as insulated from external influence as occurs in the more transparent adversarial setting of judicial review. See Nicholas Bagley \& Richard L. Revesz, Centralized Oversight of the Regulatory State, 106 CoLUM. L. REV. 1260, 1305-07 (2006) (applying public choice theory and arguing that the OIRA would be vulnerable to lobbying by interest groups). Moreover, OIRA reviews are not themselves subject to judicial review. Id. at 1309. For criticism of the OIRA process, see generally Alan B. Morrison, OMB Interference with Agency Rulemaking: The Wrong Way to Write a Regulation, 99 HARV. L. REV. 1059 (1986). 
Circuit would be less demanding in its own review of SEC rulemaking if aware that each SEC action could be, and might have been, reviewed by OIRA. In any case, rigorous review of SEC rules by the D.C. Circuit might be seen as placing SEC rulemaking on the same footing as non-independent regulatory agency rulemaking. In this sense, the recent arousal of the D.C. Circuit moves the SEC toward a level of accountability applied to many other agencies of the federal government. But, the D.C. Circuit's activism also poses a serious separation of powers issue to the extent it imposes a standard for review contrary to the one adopted by Congress. Nonetheless, the SEC's repeated efforts in setting forth costs and benefits as a separate portion of its analysis to support adoption of rules can be seen as being in step with OIRA reviews and, hence, defensive to any movement to subject the agency to OIRA.

\section{Moving Forward in the Reshaped Regulatory Landscape}

Nearly half a century ago, Richard Stewart crisply summarized the dilemma posed by judicial review of agency rulemaking to determine whether adequate consideration was given to multiple objectives Congress has set forth for the agency to consider:

[I]t is unlikely that principles or guidelines can be developed for weighing particular interests, [so that] agencies attempting to solve complex problems will be largely unable to anticipate what a subsequent reviewing court may demand of them. Even on remand, there is no assurance that the agency's best efforts to redistribute weights among the various interests will satisfy the reviewing court. The resulting oscillation between agency and court may entail enormous delays and impose substantial costs on the litigants, the agency, and the society generally. Since agencies and public interest representatives command only limited resources, such costs may seriously impair the effort to stimulate more effective agency action on behalf of unorganized interests. On the other hand, if courts sought to avoid such costs by declining to remand agency decisions for further proceedings, they would be abandoning the only effective sanction behind the adequate consideration requirement. ${ }^{148}$

There can be little doubt that the D.C. Circuit has overstepped the permissible level of review Congress intended for SEC rulemaking. The complaint is not, however, novel. Administrative law scholars, judges, and regulators have long written on the appropriate balance to be struck when judges are reviewing agency actions. ${ }^{149}$ In broad overview, the question is

148. Richard B. Stewart, The Reformation of American Administrative Law, 88 HARV. L. REV. 1667, 1784 (1975) (footnotes omitted).

149. See, e.g., Frank E. Cooper, Judicial Review of Administrative Decisions, 3 U. DET. L.J. 53, 54-55 (1940) (introducing the article's topic of balancing administrative authority and judicial review of administrative decisions); Cuthbert W. Pound, Constitutional Aspects of American 
not just that of relative competencies, pitting the technocratic staff of the agency against the generalist courts, but also involves issues of mediating interest politics that can impact the course of regulation. On this point, the ideal of an independent judiciary can be trumpeted as necessary to address the narrower group self-interest that might underlay a regulatory initiative.

Confounding these historical tensions in the case of the SEC are the multiple factors set forth in the Review Standard. As seen earlier, when Congress inserted the additional considerations of "efficiency, competition and capital formation," the Committee Report was clear in saying that these considerations were not to override the long-established criteria of investor protection. ${ }^{150}$ And, Congress assigned no weight to be given to any of the newly added factors. Moreover, assessing the probable impact of any rule is always problematic, and more so to assess the imponderable benefits and burdens of a rule on efficiency, competition, and capital formation.

One approach to this conundrum would be for the reviewing court to accord the regulatory agency deference on such indefinite, speculative, and arcane considerations, since judicial review on such a matter is beyond the court's core competency. This was the quiet life the SEC led prior to Chamber of Commerce. ${ }^{151}$ Another approach, reflected in the D.C. Circuit's interpretation, is to read into Congress's Review Standard the D.C. Circuit's own limitation. ${ }^{152}$ When this course has been taken, it has seriously eroded the discretion of the administrative agency. ${ }^{153}$ Because so much of what the SEC deals with is rulemaking that, on the one hand, produces benefits to investors, markets, market participants, and the economy as a whole that are speculative and non-quantifiable - and, on the other hand, entails costs that are easily quantifiable-it has invited a judicially contrived mandate for the SEC to rigorously set forth the case that the perceived benefits exceed the estimated costs. If that is what is required, then the D.C. Circuit has eviscerated the agency, at least in areas where challenges to its rules would be expected. But is this the course that the D.C. Circuit has begun, or is there room within its own approach to recalibrate and reach a result more consistent with Congress's intent and the role of an independent regulatory agency such as the SEC?

Administrative Law, 9 A.B.A. J. 409, 413 (1923) (questioning the extent to which administrative decisions should be exempt from judicial review); Patricia M. Wald, Judicial Review in Midpassage: The Uneasy Partnership Between Courts and Agencies Plays On, 32 TULSA L.J. 221, 221 (1996) (providing a D.C. Circuit judge's opinion on how current doctrines of judicial review work in practice).

150. See supra notes 78-79 and accompanying text.

151. See supra note 22 and accompanying text.

152. See Martin Shapiro, Administrative Discretion: The Next Stage, 92 YALE L.J. 1487, 1508 (1983) (suggesting courts can deal with uncertainty by reading statutes as placing the burden of proof on agencies, and resolving unclear situations in favor of industry).

153. See, e.g., id. (describing a case where the court read into a statute a requirement that the agency establish significant risk for low-level benzene exposure before setting a maximum exposure level as stripping the agency of its discretion). 
In a contemporary legal and political climate that is defined by a rising skepticism of government and more particularly of regulation, ${ }^{154}$ the SEC (and for that matter all independent regulatory agencies) must accept that it cannot support its rulemaking only through generalized, undeveloped assertions of a proposed rule's impact on competition, efficiency, and capital formation. Such a bald assertion is not likely to survive attack in the U.S. Supreme Court. More is always better than less, and even more so when it comes to justifying burdensome regulations in today's legal and political climate. ${ }^{155}$ Furthermore, the legislative history of the NSMIA, reviewed earlier, reflects that Congress unquestionably did expect thoughtful consideration of competition, efficiency, and capital formation whenever the SEC engages in rulemaking. ${ }^{156}$ Drive-by justifications that are dismissive of the burdens of the regulation, while once the norm for SEC rulemaking, are no longer acceptable. Hence, our analysis of the legislative history supports the result reached by the D.C. Circuit in American Equity, but not in Chamber of Commerce or Business Roundtable.

What remains in doubt is the degree of deference to be accorded the SEC. Here we should distinguish the issues posed in Chamber of Commerce and American Equity from those in Business Roundtable. In Chamber of Commerce and American Equity, the SEC launched new regulatory approaches-requiring, respectively, greater board independence and classifying a financial product as a security ${ }^{157}$ — without developing a sufficiently detailed record for either regulatory initiative. The justifications set forth were not supported empirically, but rhetorically. The agency appears to have been content to draw largely on its asserted expertise that these initiatives would improve investor protection and the proposed rule would favorably impact efficiency, competition, and capital formation.

154. See Larry Margasak, House Republicans Stepping Up Anti-Regulation Effort, HUFFINGTON POST (Dec. 2, 2011), http://www.huffingtonpost.com/2011/12/02/house-gop-antiregulation-bills_n_1125242.html (describing anti-regulation bills proposed by House Republicans in December 2011); Frank Newport, Americans Leery of Too Much Gov't Regulation of Business, GALLUP (Feb. 2, 2010), http://www.gallup.com/poll/125468/Americans-Leery-Govt-RegulationBusiness.aspx (finding 57\% of Americans are worried about too much regulation of business); Lydia Saad, At 13\%, Congress' Approval Ties All-Time Low, GalluP (Oct. 12, 2011), http://www.gallup.com/poll/150038/Congress-Approval-Ties-Time-Low.aspx (finding low approval of Congress across political affiliation).

155. A reflection of the anti-regulatory bias toward securities regulatory issues is Congress' recently enacted Jumpstarting Our Business Startups Act, which includes, among numerous provisions removing regulation for so-called "emerging growth companies" and other startups, a call on the SEC to review the disclosure regulations for registering securities so as to "modernize and simplify the registration process and reduce the costs and other burdens" associated with regulation. See Jumpstart Our Business Startups Act, Pub. L. No. 112-106, § 108, 126 Stat. 306, 313 (2012). This is the only reference, however, in the legislation to any assessments of regulatory costs and burdens.

156. See supra notes $74-77$ and accompanying text.

157. See supra notes 13-14 and accompanying text. 
Unlike the initiatives in Chamber of Commerce and American Equity, the initiative challenged in Business Roundtable - proxy access-was a response to legislation that clearly provided that the SEC's rules "may include a requirement" giving shareholders the means to nominate directors. ${ }^{158}$ By enacting that authority on that precise issue, not under some broadly written enabling statute, Congress took the big policy issue, proxy access, off the table. So viewed, it is anomalous that the entire analysis in Business Roundtable is devoted to the SEC's failings in justifying any shareholder access to the nominating process.

For example, the D.C. Circuit chastised the SEC's failure to set forth the costs corporations may incur in opposing nominees, the SEC's failure to address the probable benefits shareholder access might have on company performance, and the SEC's failure to consider whether special interest groups, most notably labor unions, would use proxy access as leverage to advance interests unrelated to increasing shareholder value. ${ }^{159}$ These are each legitimate concerns. But they are concerns that go to the core issueshareholder authority to nominate directors. Nowhere in Business Roundtable does the D.C. Circuit take note that it was Congress that addressed and answered the question of the appropriateness of shareholder access as a means for the SEC to advance its mandate.

Stunningly, Business Roundtable makes no reference whatsoever to the Dodd-Frank Act's express authorization for a rule providing proxy access or note that the SEC acted pursuant to that authority. ${ }^{160}$ The grant of authority to the SEC was not only unqualified, but clearly anticipated that the SEC would adopt a rule that provided terms and conditions for what the agency believed was appropriate proxy access. ${ }^{161}$ Congress expressly authorized the SEC to provide a mechanism for shareholder access and thereby embraced the benefits of shareholder access. The legislative history is clear that proxy access was to be provided and that Congress was deferring to the SEC to address the conditions under which such access would be available. ${ }^{162}$ The

158. See supra notes 2, 6-10 and accompanying text.

159. Bus. Roundtable v. SEC, 647 F.3d 1144, 1150-52 (D.C. Cir. 2011).

160. Dodd-Frank Wall Street Reform and Consumer Protection Act of 2010, Pub. L. No. 111203, § 971, 124 Stat. 1376, 1915 (2010).

161. See S. REP. NO. 111-176, at 146-47 (2010) (discussing proxy access and the Section's grant of great discretion to the SEC in delineating such access). While stating that $\S 972$ of the Dodd-Frank Act did not require the SEC to engage in rulemaking, it recognized that the provision gives the SEC wide latitude in terms of proxy access. Id. at 146. The report explains that "[t]he Committee feels that it is proper for shareholders, as the owners of the corporation, to have the right to nominate candidates for the Board using the issuer's proxy under limited circumstances." Id. It then proceeds to quote from the testimony of several hearing witnesses enthusiastically supporting proxy access. Id. at 146-47.

162. See id. at 146 ("The authority gives the SEC wide latitude in setting the terms of such proxy access.... If the SEC proposes rules, interested persons can offer their views on the appropriateness of proposed regulatory terms in the public comment process. The Committee feels that it is proper for shareholders, as the owners of the corporation, to have the right to nominate 
fault of Business Roundtable was failing to note this distinction from statutes at issue in its prior holdings, where Congress had not spoken directly to the topic of greater independence (except for the forty percent it had already required in the Investment Company $\mathrm{Act}^{163}$ ) or whether indexed annuities should be deemed securities.

The D.C. Circuit's analysis, by focusing exclusively on the broad policy question that Congress had taken off the table, is misdirected. By enacting Dodd-Frank, Congress embraced the broader concept of shareholder access, leaving it to the SEC to identify how that vision is to be achieved. So viewed, the D.C. Circuit's review most appropriately should have been confined to the details of the proposal, such as the three-percent- and threeyear-ownership requirements. As a consequence, the D.C. Circuit has not only flaunted the Review Standard, but has also essentially invalidated the will of Congress.

The issue raised in Business Roundtable turned on much finer (indeed, technical) points for which we might expect there would be a much stronger case for deference to the SEC since Congress had taken the larger policy question off the table. But, no doubt blinded by its own precedents, the D.C. Circuit failed to note the distinction and failed to focus on the real question posed by Rule 14a-11: whether that rule was within the authority delegated by Congress to the SEC. The question then would have been the more indefinite inquiry regarding why three years, three percent, and only a distinct minority of the board were the applicable metrics for carrying out Congress's will under the Review Standard. The following discussion suggests how questions such as these are to be considered under the Review Standard.

As seen, there are four factors the Commission is to consider in its rulemaking: investor protection, efficiency, competition, and capital formation. The operative verb in the Review Standard is "consider," so that there is no necessity that the Commission find or ensure or conclude that the proposed rule satisfies each of these factors. ${ }^{164}$ As seen in our discussion of the legislative history, the rejection of the Senate's version of the Review Standard, and the later enactment of a different standard for the CFTC while simultaneously appending the Standard to the Investment Advisers Act, support the view that Congress chose "consider" advisedly. ${ }^{165}$ "Consider," rather than "find" or "conclude," is inherently necessary for regulation pursuant to a multifactor approach like the one embraced in the Review Standard since in the complex area of financial regulation, any regulatory action is likely to fail under one or more of the factors.

\footnotetext{
candidates for the Board using the issuer's proxy under limited circumstances.”); supra notes 62-64 and accompanying text.

163. Investment Company Act of $1940 \S 10(a), 15$ U.S.C. § 80a-10(a) (2006).

164. See supra notes $62-64$ and accompanying text.

165. See supra notes 64-71 and accompanying text.
} 
The tension surrounding proxy access is an example of the problematic features of the Review Standard's embrace of these four factors. Most certainly shareholder access raises costs for a corporation which, having taken the first step to nominate through its board a management slate that it believes would best serve the corporate interest, must, when confronted with competition, take up the corporation's nominees' cause. That is, when confronted with an opposition slate through the proxy access provision, the corporation's management will not abandon its nominees, but will increase its efforts to ensure that the board-nominated nominees are elected. This necessarily means that a contest between the two slates will result; hence, there will be additional costs to the corporation. And, if the insurgents are elected, the corporation may well find their costs will be borne by the corporation, i.e., costs on costs. ${ }^{166}$ There is modest evidence regarding the amount of these costs when only a minority of the board seats is at stake, which was the most that was permitted by Rule $14 a-11 .{ }^{167}$ Note here that the benefits of the proxy access rule, to be sure, are difficult to quantify, but the costs will be evident in the incremental campaign expenditures made by the corporation. Thus, on the efficiency factor, the status quo likely gets the nod; the board controls the nominating process, thus reducing costs and uncertainty of outcome. ${ }^{168}$

Another way of stating this is that democracy in any form is more costly than a less-democratic means of operation, such as the self-perpetuating board. Competition for board seats likely produces benefits: a fuller discussion of the candidates' relative strength and their vetting, on average, might be expected to produce better qualified directors. That is, proxy access is about competition for board seats, so why would efficiency not be an easy factor to satisfy for this initiative? It is not easy to satisfy if the Review Standard's referent is not competition for board seats, but making the industry in which the issuer operates more competitive. This illustrates the

166. See DeL. CoDE ANN. tit. 8, § 113 (2011) (authorizing bylaws providing reimbursement of proxy contest expenses incurred in connection with the election of directors).

167. Facilitating Shareholder Director Nominations, Securities Act Release No. 9136, Exchange Act Release No. 62,764, Investment Company Act Release No. 29,384, 75 Fed. Reg. 56,668, 56,675 (Sept. 16, 2010) (codified at 17 C.F.R. pts. 200, 232, 240, and 249) (stating that Rule 14a-11 cannot be used by a shareholder seeking to change control of the company). Rule 14a11 was struck down by the D.C. Circuit shortly after it was enacted. Bus. Roundtable v. SEC, 647 F.3d 1144, 1148 (D.C. Cir. 2011) (discussing the costs of Rule 14a-11 and holding that the SEC acted arbitrarily and capriciously in not assessing the "economic effects of [this] new rule").

168. Broadly speaking, it is on this point that commentators appear united in their condemnation of proxy access, believing that broader interests and long-term objectives pursued by the board will be compromised by interests groups seeking short-term and narrower objectives. See, e.g., William W. Bratton \& Michael L. Wachter, The Case Against Shareholder Empowerment, 158 U. PA. L. REV. 653, 690 (2010) ("[S]hareholder empowerment will make it much more difficult for a good board of directors to resist pressures to manage to the market.”); Lisa Fairfax, Delaware's New Proxy Access: Much Ado About Nothing?, 11 TRANSACTIONS: TENN. J. Bus. L. 87, 92 (2009) ("[G]ranting all shareholders access to the proxy statement could increase the influence of shareholders with narrow or special interests ....”). 
amorphous quality, indeed open-endedness, of not just this factor but the entire spectrum of factors in the Review Standard.

Moving to the final factor, we might therefore easily conclude that proxy access is at best neutral on capital formation-gains in lowering the cost of capital associated with improved governance might easily be offset, on average, by the additional costs associated with proxy access. Here the certainty of costs is likely to be more compelling than the nonmeasurable benefit. Since proxy access can result in nominees chosen outside the otherwise watchful eye of the CEO, such access can be understood-as it is indeed championed by its proponents - to protect investors. But it is a protection that has costs, which are negatives in the efficiency and competition realms. Thus, an assessment under the Review Standard on proxy access - or for that matter most any other regulatory initiative-is unlikely to always be supportable under each of the four considerations.

When it fails under some of the criteria and squeaks by on others, should this cause the agency to withdraw from the initiative? As seen earlier, the only clear statement on this by Congress when it enacted the Review Standard in the NSMIA was that the historical concern of shareholder protection remained inviolable. ${ }^{169}$ This seems sensible; a rule that does not advance investor interests but is otherwise efficient, competitive, and promotes the aggregation of capital would be hard for the SEC to embrace. But more importantly, by choosing the verb "consider," Congress clearly called on the SEC to mediate across the four factors. What is required, as seen earlier, is a thoughtful exploration of how the four factors are likely to interact if the initiative is adopted. We believe the SEC may better be able to satisfy the "hard look" review, even one closely scrutinizing its assessment of costs and benefits, through pursuing three straightforward strategies: stop concluding, stage any sweeping initiative, and scale regulation.

\section{A. “Consider," Not Conclude-Analytical, Not Econometrical}

Dirty Harry reminds us “[a] man's got to know his limitations." "170 This may well be a lesson more easily learned by the SEC than the D.C. Circuit; in any case, as the initiating party, the SEC should try to control the terrain on which the jousting will occur. Thus, we counsel that the SEC step back from practices followed in the past, reorient its approach, and seek to prevail by shifting the lens it presents for reviewing its initiatives.

An important step forward in addressing the new review standard adopted by the D.C. Circuit is to reorient the reasoning supporting the proposed regulatory initiative. As developed above, the legislative intent surrounding the Review Standard does not require that the SEC either find, conclude, or otherwise decide that a proposed regulation improves efficiency,

169. See supra note 78 and accompanying text.

170. MAGNum ForCE (Warner Bros. Pictures 1973). 
competition, or capital formation. ${ }^{171}$ At the same time, the D.C. Circuit has not rebuffed SEC regulatory efforts for failing to fully take each of these items into consideration in a detailed manner. By appearing to conclude, as the SEC has, that each of these standards has been met, the SEC sets the stage for the reviewing court to test that conclusion against the record. As developed above and in the next two sections, determining the costs and benefits for any regulatory initiative is problematic; incompleteness of the analysis can easily be found, and has been found. This seems to be the most fundamental conclusion that can be drawn from Chamber of Commerce, American Equity, and Business Roundtable.

But our suggestion is more sweeping than avoiding any "conclusions." We counsel that the SEC in proposing its rules should do so as a lawyer, not as an econometrician or empiricist. There is a decided tone in the D.C. Circuit decisions that that court believes it is they, and not the SEC, who are the econometricians. This might be the case, although it is hard to know why that could be. Nonetheless, the SEC appears to have blindly walked into the trap it has set for itself by repeatedly framing justifications for the rule on costs and benefits. In a sense, it now finds itself hoisted by its own petard. Indeed, recent signs from the agency point to an even greater role for costbenefit analysis, and economists generally, in the SEC's future rulemaking attempts. ${ }^{172}$

Decidedly lacking in the supporting releases that accompanied each of the initiatives successfully challenged in the trilogy of cases reviewed in this Article were tightly reasoned arguments and judgments respecting how the rule actually performed under each of the factors of the Review Standard. A case in point is the governance rules adopted under the Investment Company Act that were struck down in Chamber of Commerce. The econometrics for assessing governance requirements on firm performance and value are extraordinarily problematic. For example, is governance value created in all operating conditions, when the firm is in crisis, or never?

Rather than wringing its hands over such questions, as the SEC did in its adopting release, we believe it might have been wiser to have built a qualitative case for the rule (rather than attempting the impossible by trying to build a quantitative case): First, explain that the world of mutual funds is

171. See supra notes 74-98 and accompanying text.

172. In a recently circulated internal memo, the SEC appears to have instructed its staff to provide even greater economic analysis of its proposed rules by involving economists early and often in the rulemaking process and requiring economists' approval before adopting a final rule. Sarah N. Lynch, SEC Looks to Economists for Legal Cover, REUTERS (Apr. 16, 2012), http://www.reuters.com/article/2012/04/16/us-sec-economic-analysis-idUSBRE83F16W20120416. See generally The SEC's Aversion to Cost-Benefit Analysis: Hearing Before the Subcomm. on TARP, Fin. Servs. \& Bailouts of Pub. \& Private Programs of the H. Comm. on Oversight \& Gov't Reform, 112th Cong. (2012) [hereinafter SEC's Aversion to Cost-Benefit Analysis] (statement of Mary Schapiro, Chairman, U.S. Sec. \& Exch. Comm'n) (discussing in general terms a recently circulated internal "guidance" on SEC rulemaking). 
inherently incestuous (where the outside advisor essentially handpicks the parties to negotiate the self-dealing arrangements for which the SEC was proposing more independence), then, explain in a purely analytical manner how the increased independence mandated by the rule would strengthen the fund-advisor negotiations that are otherwise infected with conflicts of interest. The point is that not all rules readily lend themselves to rigorous cost-benefit analysis. Far better in most cases to make the analytical case that identifies the problem and carefully explain how the highly textured rule addresses the problems posed. ${ }^{173}$

In this context, the rule's probable impact on efficiency, competition, and capital formation could be addressed analytically and not econometrically. Instead, the most detailed analysis in the rules challenged in Chamber of Commerce and Business Roundtable was that of the costs and benefits associated with the rule. Insufficient attention was given to the host of variables that could impact a rule's possible effects under each of these factors. Thus, we counsel that the SEC would better expend its efforts by clearly stating just what the objective sought by a given rule is, why the rule as written accomplishes that objective, the relative strengths and weaknesses of other approaches considered or suggested by the comments, what the possible impact on each of the Review Standard's factors might be, and what variables are unknown (and unknowable $a$ priori) in making those estimates.

If the SEC thoroughly set forth its reasons bearing on how a regulatory initiative, based on available information, would likely impact efficiency, competition, and capital formation, it would not be framing the issue as whether, for example, efficiency results from the rule, but rather whether the SEC has developed a record supporting its close consideration of a range of potential inputs bearing on the rule's impact on efficiency. After taking a similar approach for each of the four factors of the Review Standard, it could then justify why it is that the rule, as adopted, is an advisable course. This approach also allows for the agency, implicitly, to assign distinctly different weights to each of the Review Standard's factors, mindful that the sine qua non of any rulemaking, as stated in the NSMIA amendment to the Review Standard, is investor protection.

Costs and benefits will be part of this analysis, but conclusions as to each should be avoided. And, when the SEC does undertake analysis, albeit without "concluding," of costs and benefits it believes flow from a proposed rule, the SEC should carefully and precisely identify discrete aspects of the

173. The SEC appears to be taking small steps towards the approach we recommend: Chairman Schapiro recently testified to Congress that in the future, when a proposed rule's costs and benefits cannot reasonably be quantified, the adopting release should provide: (1) some explanation of why that is the case, and (2) a "qualitative analysis of the likely economic consequences of the proposed rule.” SEC's Aversion to Cost-Benefit Analysis, supra note 172, at 16 (statement of Mary Schapiro, Chairman, U.S. Sec. \& Exch. Comm’n). 
rule it included to minimize potential costs and, likewise, should identify provisions of the rule likely to maximize the benefits of the rule.

\section{B. Staging Regulation}

For decades, the exclusive domain for trading in stocks listed on the New York Stock Exchange was the NYSE. ${ }^{174}$ This was not because of any natural forces; it was because NYSE's Rule 390 prohibited off-board trading. ${ }^{175}$ This monopoly, comfortable for the NYSE and its members but less comfortable for others, began to weaken when the SEC, in June 1980, adopted Rule 19c-3, permitting securities listed after April 26, 1979, to be traded elsewhere. ${ }^{176}$ In this way, the SEC created natural conditions for observing the pricing and general market effects for securities that were

174. See Tai-Kong Kam et al., Competition Among Markets: The Repeal of Rule 390, 27 J. BANKING \& FiN. 1711, 1712 (2003) (stating that Rule 390's prohibition on trading stocks off of the exchange dated back to the 18th century).

175. Id.

176. The table for challenging the New York Stock Exchange's off-board trading restrictions was set by amendments to the 1975 Securities Act that, among other features, directed the SEC to "facilitate the establishment of a national market system." Securities Act Amendments of 1975, Pub. L. No. 94-29, § 7, 89 Stat. 97, 112 (1975) (codified as amended at 15 U.S.C. § 78k-1 (2006)). Congress also required the SEC "to review any and all rules of national securities exchanges which limit or condition the ability of members to effect transactions in securities otherwise than on such exchanges" and report its finding to Congress as well as commence proceedings "to amend any such rule imposing a burden on competition which does not appear to the Commission to be necessary or appropriate.” Id. at § 7(c)(4)(A). The industry resisted the notion that competition was desirable or would be enhanced by relaxing the off-board trading rule. See Wall Street Firms Defend Rules Favoring Members of Exchange, N.Y. TiMES, Sept. 25, 1975, at 67 (describing a letter by twenty-two Wall Street firms expressing their uniform opinion that the benefits of relaxing the off-board rule would be dwarfed by the resulting costs). While the SEC did propose Rule 19c-2, which would have repealed the restriction outright, Announcement of Proceeding Regarding Exchange Off-Board Trading Rules, Exchange Act Release No. 13,662, 12 SEC DIGEST 947 (proposed June 23, 1977), it ultimately withdrew that proposal and adopted Rule 19c-3, which tested the impact of removing the off-board trading restrictions by holding that securities listed after April 26, 1979 would not be subject to that restriction. Off-Board Trading Restrictions, Exchange Act Release No. 16,888, 45 Fed. Reg. 41,125, 41,127 (June 18, 1980) (codified at 17 C.F.R. pt. 240) ("The Commission ... believes that the Rule is justified by its experimental value which will further the purposes of the Act by providing actual experience with the effects of concurrent overthe-counter and exchange trading.").

Further experimentation occurred, albeit as a result of pressure from Congress, when the SEC initiated for thirty companies, during a test period of six months, a linkage among seven stock exchanges and the OTC market to see if their trading would move away from their prime-listed market. Electronic Link of 7 Exchanges; OTC Will Begin, WALL ST. J., May 7, 1982, at 5.

The NYSE repealed Rule 390 in December 1999 and the SEC approved its actions in 2000. NYSE Rulemaking: Order Approving Proposal to Rescind Exchange Rule 390, Exchange Act Release No. 42,758, 65 Fed. Reg. 30,175, 30,176 (May 10, 2000). The repeal had the broad support of Wall Street, which saw business being drawn away from the exchanges by the various proprietary electronic communications networks where trades could be executed more quickly and cheaply than on the NYSE. See Robert Sales, The Quest to Kill 390, WALL ST. \& TECH., Dec. 1999, at 37, 37 (contending that executives of the largest broker-dealers on Wall Street had all vocalized opposition to Rule 390). By then, Rule 390 covered only $30 \%$ of the NYSE-listed issuers who represented approximately half of the exchange's volume. Id. at 38. 
traded exclusively on the NYSE and those that were traded in multiple venues, including the NYSE.

More recently, the SEC purposely created a climate for a natural experiment when, in May 2005, it commenced a pilot program whereby onethird of the Russell 3000 Index constituent stocks with high levels of liquidity were exempted from the Uptick Rule. ${ }^{177}$ The Uptick Rule, former Exchange Act Rule 10a-1, was designed to prevent short sellers from accelerating a declining market by providing that a listed security might be sold short only at either a price above where the immediately preceding sale was effected (the plus tick) or at the last price if it was higher than the last different price (zero-plus tick). ${ }^{178}$ With very limited exceptions, short sales were prohibited on the minus tick or zero-minus ticks. Collectively these are known as the Uptick Rule. ${ }^{179}$

Both Rule 19c-3 and the pilot program preceded significant changes in the operating rules of trading markets. The Uptick Rule had been a feature of American securities regulatory policy since $1938 ;{ }^{180}$ the bar to off-board trading has an even longer history, since exchanges historically embodied this anticompetitive feature. ${ }^{181}$ Thus, the SEC, perhaps timidly, but certainly wisely, tested the waters before launching those reform efforts. This not only made good politics, but made better-informed regulatory policy.

The most obvious benefit of staging is that it informs the ultimately embraced regulatory policy. The SEC's actions with both Rule 19c-3 and the pilot program created a natural experiment by which the impact of differing

177. See Short Sales, Exchange Act Release No. 50,103, 69 Fed. Reg. 48,008, 48,012-13 (Aug. 6, 2004) (adopting proposed rule 202T, allowing the SEC to establish a pilot program "to suspend any short sale price test for such securities and for such time periods as the Commission deems necessary or appropriate"). The one-third were chosen by selecting every third company on a list, starting with the second company. Lynn Bai, The Uptick Rule of Short Sale Regulation: Can It Alleviate Downward Price Pressure from Negative Earnings Shocks?, 5 RUTGERS BUS. L.J. 1, 11 (2008). This provided a control group of the companies not included in the pilot study sample. Id. at 5 .

178. For an overview of the history of the Uptick Rule, see generally Charles M. Jones, Shorting Restrictions: Revisiting the 1930s, 47 FIN. REV. 1 (2012).

179. See Jonathan R. Macey et al., Restrictions on Short Sales: An Analysis of the Uptick Rule and Its Role in View of the October 1987 Stock Market Crash, 74 CORNELL L. REV. 799, 800-01 (1989) ("The uptick rule, Rule 10a-1, implemented in the wake of the 1929 crash and changed only slightly since then, states that a 'short sale can only occur at a price above ("price tick") the immediate sale price, or at a price equal to the price of the most immediate sale if the most recent price change was positive."'). For critics of the revisions to the Uptick Rule, see generally David P. McCaffrey, Review of the Policy Debate over Short Sale Regulation During the Market Crisis, 73 AlB. L. REV. 483 (2010); Melissa W. Palombo, Note, The Short-Changing of Investors: Why a Short Sale Price Test Rule Is Necessary in Today's Markets, 75 BROOK. L. REV. 1447 (2010).

180. Charles R. Schwab, Restore the Uptick Rule, Restore Confidence, WALL ST. J., Dec. 9, 2008, http://online.wsj.com/article/SB122878208553589809.html.

181. See Robert A. SChWARtZ, Micro Markets: A MARKET Structure Approach to MiCROECONOMIC ANALYSIS 386 (2010) ("Fixed commissions and off-board trading restrictions were established by an accord known as the Buttonwood Tree Agreement that was signed by 24 securities brokers on May 17, $1792 \ldots .$. ”). 
regulatory treatments could be empirically tested. ${ }^{182}$ Not only did this make the careers of many an academic (for whom the currency of the realm is a working paper focused on the econometric analysis of a real problem), but that work produced valuable input to the regulator, and free of charge. To be sure, the SEC has a very able and relatively well-supported group of economists who regularly opine on the costs and benefits of a proposed rule. But, one empirical study rarely can be expected to reflect the full field of possible inputs on a matter. The SEC's budget is limited in the number of studies it can launch, and the internal time constraints for the agency to consider a single issue all weigh in favor of creating an environment for others to carry out the empirical inquiry, inviting the assistance of tenureand chair-bound empiricists.

Staging has another virtue, particularly when the initiative is something of a paradigm shift, like the governance proposals at issue in Chamber of Commerce. Staging fosters an environment where much more information will be at hand before the final regulatory step is taken. Moreover, moving forward cautiously with a pilot group of firms is most consistent with the "consider" standard, since that strategy is designed to better inform the agency of the expected costs and benefits of moving forward.

As discussed earlier, costs loom large in the regulatory quilt because they are more tangible and because the cost part of the regulatory equation poses few doubts about correlation versus causation. ${ }^{183}$ Assessing benefits is quite the opposite, particularly ex ante. Ex parte research on both of these might well be seen as more credible, and what is observed ex post is likely to be received as even more credible than what is conjectured ex ante. Discrete staging allows evidence to be gathered as to costs, and allows the researcher to gather information as to the probable benefits as well.

182. E.g., Bai, supra note 177 (conducting an empirical analysis of the effects of the Uptick Rule); Kalman J. Cohen \& Robert M. Conroy, An Empirical Study of the Effect of Rule 19c-3, 33 J.L. \& ECON. 277 (1990) (studying the effects of Rule 19c-3); Karl B. Diether et al., It's SHO Time! Short-Sale Price Tests and Market Quality, 64 J. FIN. 37 (2009) (examining the effects of the suspension of short-sale price tests). The SEC also studied the effects of the experiment. E.g., DIV. MKT. Regulation, U.S. SEC, Study III: Market Fragmentation, Competition, and Regulation, in SEC MARKET 2000: AN EXAMINATION OF CURRENT EQUITY MARKET DEVELOPMENTS III-10 (1994) (finding a "limited amount of internalization" resulting from the removal of some off-board restrictions and concluding that the Division was "not surprise[d] that studies both have failed to show a strong negative effect from Rule 19c-3 or strong evidence that the additional competition in these stocks has appreciably improved their markets”); OFFICE OF ECON. ANALYSIS, U.S. SEC, ECONOMIC ANALYSIS OF THE SHORT SALE PRICE RESTRICTIONS UNDER THE REGULATION SHO PILOT 4-5 (2007), available at http://www.sec.gov/news/studies/2007/regshopilot020607.pdf (analyzing the economic impact of the SHO pilot).

183. See supra notes 163-164 and accompanying text. 


\section{Can the Public Interest Be Scaled?}

Regulatory initiatives are frequently confronted by the complaint that "one size does not fit all."184 The complaint in fact seeks scaling regulation, so that larger and more complicated firms are subject to requirements that are different from those of smaller, less complex business organizations. In the securities regulation area, scaling is typically associated with more regulation for bigger firms and less for smaller firms. ${ }^{185}$ Moreover, several initiatives embraced by the Dodd-Frank Act expressly call on the SEC, when issuing rules pursuant to the Act's provisions, to consider whether the burdens would be disproportionately greater on smaller companies.

There are at least a couple of reasons why regulation, particularly disclosure-oriented regulation, might pose greater burdens on smaller companies than larger ones. First, financial reporting, and indeed, a good deal of regulation generally, has a high fixed-cost component, so that a substantial part of the cost of compliance is invariant, or nearly so, to firm size and complexity. Second, firms that are large in terms of their total assets or revenues frequently involve complex organization structures and have operations in multiple locations that are sometimes on different continents. Complexity poses its own challenges to the efficacy of the firm's reporting system so that greater attention to the internal financial controls is necessary. In contrast, in a smaller, less complex entity, the senior management has a greater awareness of daily operations so that there is less need for the procedures employed in larger, more complex organizations for protecting the integrity of internal financial reporting. Thus, a few of the disclosure demands in SEC Regulation S-K, for example, are less demanding for smaller companies than for larger ones. ${ }^{186}$ On the other hand, SEC rules

184. See Amy Feldman, Surviving Sarbanes-Oxley, INC. MAG., Sept. 2005, at 132, 137 ("Many observers believe there ought to be different rules for companies of different sizes, or at least clearer guidelines on how small companies should apply the rules.”); Public statement from Marshall E. Blume \& Chester S. Spratt, Shadow Fin. Regulatory Comm., The Equity Markets: One Size Does Not Fit All (Feb. 22, 2010), available at

http://www.aei.org/files/2010/02/22/Statement\%20No.\%20287.pdf (reviewing the SEC’s proposed rules, and noting that "the trades of small retail investors and institutional investors are fundamentally different and should not be viewed as interchangeable").

185. See Troy A. Paredes, Comm'r, U.S. Sec. \& Exch. Comm'n, Twelfth Annual A.A. Sommer, Jr. Lecture on Corporate, Securities and Financial Law (Oct. 27, 2011), available at http://www.sec.gov/news/speech/2011/spch102711tap.htm (“[T]he federal securities laws have long recognized the need to be measured, as there is a tradition of scaling federal securities regulation in important respects to provide small businesses relief from select burdens that may be especially onerous for them.").

186. E.g., 17 C.F.R. § 229.101(h) (2011) (setting out lesser reporting obligations); id. at $\S 229.201$ (e) (allowing for the election of an appropriate index to use in the preparation of reports); id. at $\S 229.303(\mathrm{a})$ ("[T]he discussion shall focus on each relevant, reportable segment or other subdivision of the business and on the registrant as a whole.”). Most recently, Dodd-Frank excused non-accelerated filers, those with a market capitalization (excluding shares of affiliates) less than $\$ 75$ million from the auditor attestation of management's assessment of internal controls. See Press Release, American Accounting Association, Reviled Though It Has Been, Sarbanes-Oxley's Section 404 Substantially Reduces Corporate Financial Misstatements, Study Finds (Nov. 16, 
grant many regulatory dispensations to very large companies because their shares are believed to trade in deep markets, with broad analyst coverage, and with significant institutional ownership. ${ }^{187}$ Hence, there is a history of scaling of regulation under the federal securities laws.

Scaling regulation so as to provide important dispensations to smaller companies immediately confronts serious public interest concerns because studies continue to reflect, as captured above, that there is a higher frequency of financial fraud and, more generally, reporting weaknesses in smaller companies than in larger companies. That is, reporting problems are in a sense reverse-scaled. Small companies pose a greater frequency of risk to investors than do larger companies. Nonetheless, scaling has to some extent the same virtues as staging. Each allows something of a test period before standards are imposed. In the case of small issuers, they enjoy lightened regulation until more is learned about whether their regulatory burdens should be increased. Scaling also communicates not just deliberateness on the part of the SEC, but discreteness that is consistent with the Review Standard. With both staging and scaling, regulation would be more evolutionary, which should have its positive impact when a staged or scaled rule is challenged under the Review Standard.

\section{Conclusion}

So what to make of the mischief of Chamber of Commerce and Business Roundtable? Their author has now left the bench, but the issue remains: how close a review is the court to undertake of SEC rules? As matters now stand, a good deal of uncertainty surrounds any SEC rulemaking that engenders the ire of the regulated. Indeed, we repeatedly hear the rattling of appellatereview sabers by industry groups. ${ }^{188}$ We have gone to some effort to make

2010), available at http://aaahq.org/newsroom/Sarbanes-Oxley\%27sSection404.htm (“[T]his year’s Dodd-Frank financial-reform bill permanently exempts companies with less than \$75-million capitalization from a key provision of 404 that requires an outside auditor to attest annually to firms' internal-control evaluations.”).

187. See, e.g., 17 C.F.R. §§ 229.10(f), .101(h), .301(c), .407(g) (2011) (reducing or eliminating many of Regulation S-K's reporting requirements for smaller companies); Securities Offering Reform, Securities Act Release No. 8501, Exchange Act Release No. 50,624, Investment Company Act Release No. 26,649, 69 Fed. Reg. 67,392, 67,396-97 (proposed Nov. 17, 2004) (codified as amended at 17 C.F.R. pts. 228, 229, 230, 239, 240, 243 and 274) (justifying the SEC's decision to provide large companies (well-known seasoned issuers) with greater disclosure and registration flexibility by stating that issuers with high levels of market capitalization also tend to have high levels of analyst coverage and institutional ownership, and, thus, high levels of market scrutiny); Daniel J. Morrissey, The Securities Act at Its Diamond Jubilee: Renewing the Case for a Robust Registration Requirement, 11 U. PA. J. BUS. L. 749, 763 (2009) (observing that the SEC rules give large companies (seasoned issuers and well-known seasoned issuers) more freedom to conduct offering activity during the registration process).

188. See, e.g., Groups, Stressing Economic Impact, Ask SEC to Host Roundtable on Pay Ratio Rulemaking, 44 SEC. REG. \& L. REP. 153 (2012) (detailing the requests for the SEC to better consider economic impact in conducting pay-ratio rulemaking); Yin Wilczek, Democratic Lawmakers Urge SEC to Adopt 'Strong' Resource Extraction Disclosure Rule, 44 SEC. REG. \& L. 
the point that Congress and the Supreme Court do not support the reasoning in either of these opinions. The strategies advanced in Part IV may smooth the path in future regulatory efforts. We are hopeful that the course of action we counsel, particularly that of staging and scaling, will be more than a mild palliative. We also believe the purposes of our suggestions are broader than sliding a rule past the D.C. Circuit; we believe each of the suggestions will lead to better regulations. With regulation anchored in the protection of investors and the public interest, much more is at stake in SEC rulemaking than just getting approval of the D.C. Circuit. But those greater goals depend on surviving a challenge to the rule the SEC has crafted to serve the public interest.

REP. 256 (2012) (reporting that American Petroleum Institute's comment letter was a roadmap for appellate review if the SEC adopts any rules related to carrying out the Dodd-Frank mandate for disclosures related to payments made by exploration companies to foreign governments); Yin Wilczek, Industry Calls on SEC to Re-Assess Economic Impact of Conflict Minerals Rule, 43 SEC. REG. \& L. REP. 2256 (2011) (speculating that despite a statutory mandate the SEC would face stiff challenges with the new rule related to conflict minerals mandated by Dodd-Frank). 